\title{
Origin and migration of oil from the Ukrainian Outer Carpathians to their Mesozoic basement: the case of the Lopushna traps
}

\author{
Natalia Y. RADKOVETS ${ }^{1, *}$, Maciej J. KOTARBA ${ }^{2}$, Yuriy V. KOLTUN ${ }^{1}$, Adam KOWALSKI ${ }^{2}$, \\ Paweł KOSAKOWSKI ${ }^{2}$ and Dariusz WIĘCŁAW ${ }^{2}$
}

\footnotetext{
1 National Academy of Sciences of Ukraine, Institute of Geology and Geochemistry of Combustible Minerals, Naukova 3a, 79060 Lviv, Ukraine

2 AGH University of Science and Technology, Faculty of Geology, Geophysics and Environmental Protection, al. A. Mickiewicza 30, 30-059 Kraków, Poland
}

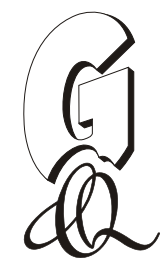

Radkovets, N.Y., Kotarba, M.J., Koltun, Y.V., Kowalski, A., Kosakowski, P., Więcław, D., 2016. Origin and migration of oil from the Ukrainian Outer Carpathians to their Mesozoic basement: the case of the Lopushna traps. Geological Quarterly, 60 (1): 133-148, doi: 10.7306/gq.1256

The Lopushna oil field has been discovered in Mesozoic-Paleogene strata of the platform basement beneath the Ukrainian Outer (Flysch) Carpathians. Oils from two main accumulations, occurring in Upper Cretaceous sandstone and Upper Jurassic limestone reservoirs, have been analysed in order to identify their origin and relation to the known petroleum systems in the region of the Outer Carpathians and the basement of the Carpathian Foredeep. Results of geochemical investigations of oils, including biomarker and isotopic data, show a good correlation with oils accumulated in Carpathian flysch strata. The oils are low-sulphur and did not undergo significant degradation. They were generated from Type II or II/III kerogen, deposited in anoxic environments in clastic sediments. Generation occurred at the peak of "oil window", probably in the temperature range of 122 to $126^{\circ} \mathrm{C}$. The presence of oleanane indicates Cretaceous or younger source rocks. Good correlation of biomarker and isotopic data with the organic matter dispersed in the Oligocene Menilite Beds occurring at the top of the Carpathian flysch succession allowed identification of these as source rocks for oils of the Lopushna field, which thus can be regarded as an oil family of the Outer Carpathians. The migration distance for both the Lopushna oils and oils accumulated in the Carpathian flysch strata was similar. A number of sub-vertical dislocations, along which the subsided flysch strata occur at the same depth level as the Jurassic and Cretaceous rocks of the platform, can be assumed as possible migration pathways from the mature source rocks of the Oligocene Menilite Beds of the Boryslav-Pokuttya, Skyba or Krosno units to the Lopushna type traps, which suggests the possibility of existence of other hydrocarbon accumulations of this type. The Lopushna field so far is unique in containing this type of oil found in the basement of the Ukrainian Carpathian Foredeep.

Key words: Ukrainian Carpathians, Lopushna oil field, oil origin, biomarkers, stable carbon isotopes, migration pathways

\section{INTRODUCTION}

The Ukrainian Carpathians belong among the largest petroleum provinces of Central Europe. Oil production started there in 1854, while natural gas production began in 1921 (Fedyshyn 1998; Fedyshyn et al., 2001). The Ukrainian part of the Carpathian Petroleum Province is now at the advanced stage of petroleum exploration.

The main aspects of petroleum generation and accumulation in the area of the Ukrainian Carpathians have been discussed in earlier publications (Koltun, 1992; Koltun et al., 1998 Kotarba et al., 2005, 2007; Kotarba and Koltun, 2006; Więcław et al., 2012). The principal source rocks have been recognized and investigated, whereas oils and natural gases have been

\footnotetext{
* Corresponding author, e-mail: radkov_n@ukr.net
}

Received: August 16, 2015; accepted: September 12, 2015; first published online: October 19, 2015 studied with respect to their genetic characteristics. On this basis three main petroleum systems have been identified, namely the petroleum system of the Cretaceous-Paleogene flysch sequence of the Outer Carpathians (Koltun et al., 1998), which includes the main oil fields of the Carpathian Province, the petroleum system of the Neogene molasse of the Carpathian Foredeep (Kotarba et al., 2011a), which includes the main gas fields, and the petroleum system of the basement of the Outer Carpathians and Carpathian Foredeep (Kotarba et al., 2011b) comprising several oil fields in the Mesozoic sequence of the East European Platform, and occurring on both sides of the Polish-Ukrainian border.

A significant part of the Ukrainian Mesozoic-Paleogene basement occurs beneath the thrust belt, representing an important new target for petroleum exploration. It is known (Picha, 1996) that petroleum fields of this type have shown great potential in a number of basins. The Lopushna field has been discovered in Mesozoic-Paleogene strata of the platform basement beneath the Carpathian Overthrust in the area close to the Romanian border (Fig. 1) and was perceived as a site where a new type of field can be discovered in the Carpathian region. In 


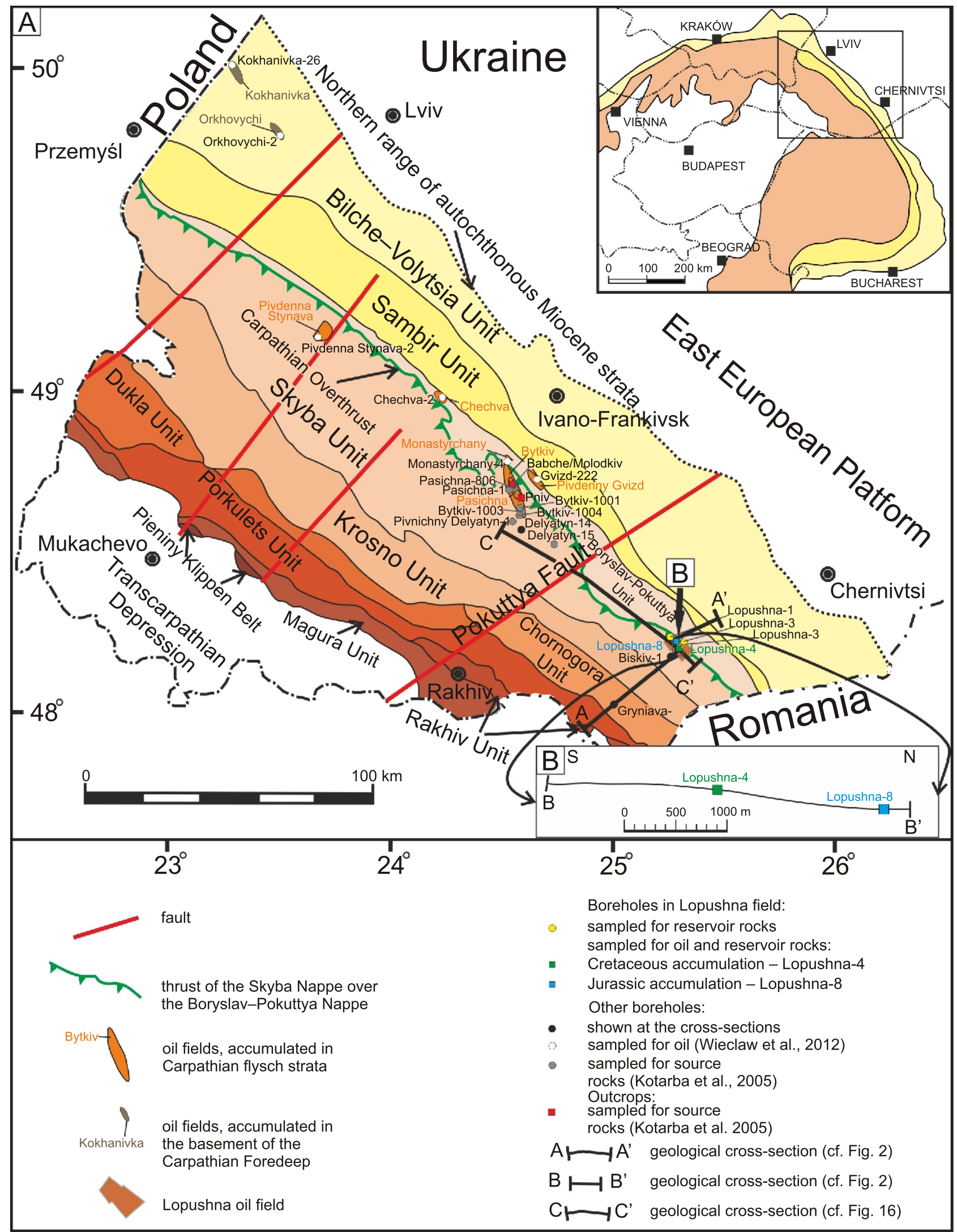

Fig. 1. Sketch geological map showing location of the main tectonic units of the Ukrainian Carpathians, location of cross-sections (see Figs. 2 and 16), the Lopushna oil field and crude oil and reservoir rock sampling sites 


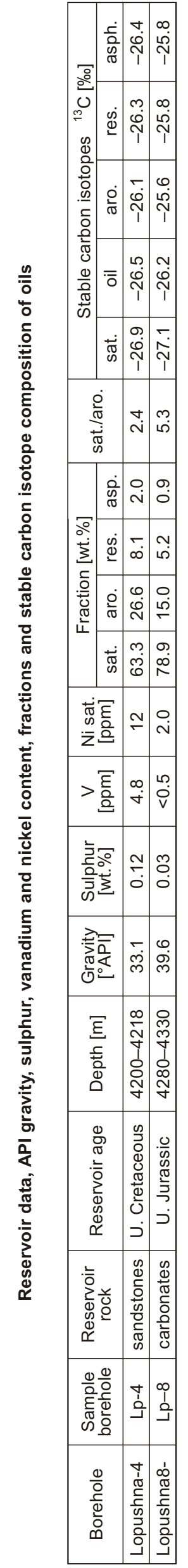

1984, the Lopushna-3 borehole produced oil from the Albian-Cenomanian sandstone reservoir with a flow rate of 283.4 ton/day. Since that time there has been production in this field. The initial recoverable reserves of oil are 6401 thousand tons and dissolved gas on-going 1162 million $\mathrm{m}^{3}$ (Fedyshyn, 1998). Though accumulated in a similar stratigraphic setting to the oils from the Ukrainian Mesozoic basement near the Polish-Ukrainian border (Kokhanivka and Orkhovychi fields), these oils differed in their physical and chemical characteristics and thus the Lopushna field remained an unsolved problem in the understanding of the interrelation of the petroleum systems in the region of the Ukrainian Carpathians. Earlier investigations (Lafargue et al., 1994; Roure and Sassi, 1995; Picha, 1996) suggested that oil migrated to the Lopushna reservoirs from the Oligocene Menilite Beds of the Outer Carpathians before the main overthrusting event. However, the data obtained by others (Koltun et al., 1998) show that the Menilite Beds reached the maturation level, corresponding to the "oil window", only after the Miocene overthrusting episode and mature source rocks occur at depths exceeding $4.5 \mathrm{~km}$. Krzywiec et al. (2009) considered that Albian shales of the Mesozoic basement might be the source of the Lopushna oil accumulations. However, the small thickness, poor TOC content and Type III kerogen of these dark-coloured rocks (Radkovets, 2010, 2015; Kosakowski et al., 2012) which, according to palaeontological investigations (Gavrylyshyn, 1998; Ogorodnik, 2005), are dated as Barremian-Aptian make this option hardly viable. Ten Haven et al. (1993) and Curtis et al. (2004) have considered the Oligocene Menilite Beds to be an important source rock for most oils accumulated in the Mesozoic (Upper Jurassic and Upper Cretaceous) basement of the Polish Carpathians. Więclaw (2011) described many oil families in the Paleozoic-Mesozoic basement in the Polish part of the Carpathian Foredeep and showed that Silurian, Devonian, Lower Carboniferous, Middle and Upper Jurassic strata are the probable source rocks for these oils.

The objective of this study is to characterize oils from the Lopushna reservoirs, as well as to identify their source rocks, maturity and possible migration pathways. One question remains: what is the origin of oil in the Lopushna field? Does it represent a separate petroleum system, or does it belong to a known one? The solution of this problem is important for deeper understanding of the processes of petroleum generation, migration and accumulation, and for assessment of the possibility of new discoveries in the platform strata beneath the Ukrainian Carpathian Overthrust. This paper for the first time presents the results of petrographic study of the reservoir rocks and the geochemical analyses of the oils: the density, sulphur, nickel and vanadium contents, whole oil GC, stable carbon isotopes and biomarker composition of oils from the Lopushna field.

\section{METHODOLOGY}

\section{OIL AND ROCK SAMPLING SITES AND PROCEDURE}

Two oil samples were collected from the producing boreholes Lopushna-4 and Lopushna-8. In the Lopushna-4 borehole an oil sample was taken from Upper Cretaceous (Cenomanian) sandstones, from the interval of 4200-4218 m, while in the Lopushna-8 borehole the Upper Jurassic limestones and the interval of 4280-4330 m was sampled (Table 1). Oil samples collected to $1-\mathrm{L}$ glass containers were purified from mechanical contamination before analyses by centrifugating (1500 rpm during $5 \mathrm{~min}$ ). 
Petrographic composition of the reservoir rocks

\begin{tabular}{|c|c|c|c|c|c|c|c|c|c|c|c|c|c|c|c|c|}
\hline \multirow{4}{*}{ Borehole } & \multirow{4}{*}{$\begin{array}{l}\text { Sample } \\
\text { code }\end{array}$} & \multirow{4}{*}{$\begin{array}{l}\text { Reservoir } \\
\text { stratigraphy }\end{array}$} & \multirow{4}{*}{ Lithology } & \multirow{4}{*}{ Depth [m] } & \multicolumn{12}{|c|}{ Components } \\
\hline & & & & & \multicolumn{3}{|c|}{ Clastic } & \multicolumn{2}{|c|}{ Authigenic } & \multicolumn{2}{|c|}{$\begin{array}{l}\text { Carbon- } \\
\text { ate }\end{array}$} & \multirow{2}{*}{$\begin{array}{l}\begin{array}{l}\mathrm{Cla} \\
\text { yey }\end{array} \\
\mathrm{Hm}\end{array}$} & \multicolumn{2}{|c|}{$\begin{array}{l}\text { Acces- } \\
\text { sory }\end{array}$} & \multicolumn{2}{|c|}{ Ore } \\
\hline & & & & & $Q$ & $\mathrm{FI}$ & Ms & $\mathrm{GI}$ & Pht & $\mathrm{Ca}$ & $\mathrm{DI}$ & & $\mathrm{Zr}$ & $\mathrm{Ep}$ & $\mathrm{Pr}$ & II \\
\hline & & & & & \multicolumn{12}{|c|}{ \% composition } \\
\hline Lopushna-4 & Lp-4/1 & U. Cretaceous & sandstone & 4213.8 & 70 & 1 & 2 & 4 & 2 & 5 & 5 & 8 & 1.5 & 0.8 & 0.5 & 0.2 \\
\hline Lopushna-4 & Lp-4/2 & U. Cretaceous & sandstone & 4212 & 55 & 0.5 & 3 & 5 & 2 & 8 & 6 & 15 & 0.2 & 0.2 & 0.1 & 0.5 \\
\hline Lopushna-4 & Lp-4/3 & U. Cretaceous & sandstone & 4215.8 & 60 & 1 & 0.5 & 3 & 0.5 & 10 & 10 & 10 & 1 & 0.5 & 3 & 0.5 \\
\hline Lopushna-4 & Lp-4/4 & U. Cretaceous & sandstone & 4210.7 & 50 & 2 & 0.2 & 20 & 10 & 5 & 5 & 5 & 0.5 & 0.1 & 2 & 0.2 \\
\hline Lopushna-3 & Lp-3/5 & U. Cretaceous & sandstone & $4187-4188$ & 70 & 0.2 & 0.1 & 8 & 5 & 7 & 2 & 5 & 0.2 & n.d. & 1.5 & 1 \\
\hline Lopushna-3 & Lp-3/6 & U. Jurassic & limestone & $4294-4300$ & 10 & n.d. & n.d. & n.d. & n.d. & 60 & 15 & 12 & n.d. & n.d. & 3 & n.d. \\
\hline Lopushna-11 & Lp-11/7 & U. Jurassic & limestone & $4290-4295$ & 7 & n.d. & n.d. & n.d. & n.d. & 50 & 30 & 10 & n.d. & n.d. & 3 & n.d. \\
\hline Lopushna-4 & Lp-4/8 & U. Jurassic & limestone & $4360-4368$ & 2 & n.d. & n.d. & n.d. & n.d. & 65 & 25 & 15 & n.d. & n.d. & 3 & n.d. \\
\hline Lopushna-11 & Lp-11/9 & U. Jurassic & limestone & $4135-4143$ & 2.5 & n.d. & n.d. & n.d. & n.d. & 60 & 25 & 12 & n.d. & n.d. & 0.5 & n.d. \\
\hline Lopushna-13 & Lp-13/10 & U. Jurassic & limestone & $5138-5144$ & 5 & n.d. & n.d. & n.d. & n.d. & 55 & 25 & 13 & n.d. & n.d. & 2 & n.d. \\
\hline \multicolumn{17}{|c|}{ Average } \\
\hline & & U. Cretaceous & sandstones & & 61 & 0.9 & 1.1 & 8 & 3.9 & 6 & 5.6 & 8.6 & 0.7 & 0.3 & 1.4 & 0.5 \\
\hline & & U. Jurassic & carbonates & & 5.3 & n.d. & n.d. & n.d. & n.d. & 58 & 24 & $\begin{array}{c}12 . \\
4\end{array}$ & n.d. & n.d. & 2.3 & n.d. \\
\hline
\end{tabular}

U. - Upper; Q - quartz; FI - feldspar; Ms - muscovite; GI - glauconite; Pht - phosphate; Ca - calcite; DI - dolomite; Hm - hydromica; Zr - zircon; Ep - epidote; Pr - pyrite; II - IImenite; n.d. - not determined

Ten available core samples of Upper Jurassic limestone and Upper Cretaceous sandstone reservoir rocks were collected from the Lopushna-3, $-4,-11$ and -13 boreholes for ore petrographic study (Table 2).

\section{ANALYTICAL PROCEDURE}

Oils were analysed for API gravity with an Anton Paar $D M A 5300 M$ density meter and for sulphur content with a Leco $S R-12$ analyser. The vanadium and nickel contents were determined by the ICP-OES method using a Perkin Elmer WMA400 spectrophotometer according to the ASTM D 5708:2002 standard. Before deasphalting, oils were topped (removing gaseous fraction) under nitrogen (5 hrs) at a temperature of $60^{\circ} \mathrm{C}$. The asphaltene fraction was precipitated with $n$-hexane. The remaining maltenes were then separated into compositional fractions of saturated hydrocarbons, aromatic hydrocarbons and resins by column chromatography, using alumina/silica gel ( $2: 1$ $\mathrm{v} / \mathrm{v})$ columns $(0.8 \times 25 \mathrm{~cm})$. The fractions were eluted with $n$-hexane, toluene, and toluene:methanol $(1: 1 \mathrm{v} / \mathrm{v})$, respectively. Oils and their individual fractions for the measurement of stable carbon isotope composition were combusted in an on-line system. The stable carbon isotope analyses were performed using a Finnigan Delta Plus mass spectrometer. The stable carbon isotope data are shown in the $\delta$-notation relative to the V-PDB standard (Coplen, 2011), with the analytical precision estimated to be $\pm 0.2 \%$. The elemental composition of asphaltenes was measured on the Carlo Erba EA1108 elemental analyser.

For the whole oil analysis, high-resolution gas chromatography was used according to the methodology described by Więcław et al. (2010). The isolated saturated hydrocarbon fractions from the oils were diluted in isooctane and analysed by GC-MS for biomarker determination. The analysis was carried out with an Agilent $7890 \mathrm{~A}$ gas chromatograph equipped with an Agilent $7683 B$ automatic sampler, an on-column injection chamber and a fused silica capillary column $(60 \mathrm{~m} \times 0.25 \mathrm{~mm}$ i.d.) coated with a $95 \%$ methyl $/ 5 \%$ phenylsilicone phase (DB-5MS, $0.25 \mu \mathrm{m}$ film thickness). Helium was used as a carrier gas. The GC oven was programmed: $80^{\circ} \mathrm{C}$ held for $1 \mathrm{~min}$, then increased to $120^{\circ} \mathrm{C}$ at a rate of $20^{\circ} \mathrm{C} / \mathrm{min}$, then increased further to $300^{\circ} \mathrm{C}$ at a rate of $3^{\circ} \mathrm{C} / \mathrm{min}$ and finally held for $35 \mathrm{~min}$. The gas chromatograph was coupled with a $5975 \mathrm{C}$ mass selective detector (MSD). The MS was operated with an ion source temperature of $230^{\circ} \mathrm{C}$, an ionisation energy of $70 \mathrm{eV}$, and a cycle time of $1 \mathrm{sec}$ in the mass range from 45 to 500 Daltons. In the selected ion mode (SIM) the dwell time of the operated MSD was set to 30 milliseconds for each ion.

The aromatic hydrocarbon fractions of the oils were analysed by GC-MS for determination of phenantrene, dibenzotiophene and their derivatives. The analysis was carried out using the same equipment as for the saturated hydrocarbons fraction. The $\mathrm{GC}$ oven was programmed from 40 to $300^{\circ} \mathrm{C}$ at a rate of $3^{\circ} \mathrm{C} \mathrm{min}{ }^{-1}$. The MS was operated with a cycle time of $1 \mathrm{sec}$ in the mass range from 40 to 600 Daltons.

Petrographic investigations of the reservoir rocks have been performed on thin sections of the core samples, which were examined under a Carl Zeiss Jena polarizing microscope. X-ray diffraction (XRD) was performed on an $A D P$-2 diffractometer (Fe-anticathode, Mn-filter, $32 \mathrm{kV}, 12 \mathrm{~mA}$, counter rate 1 degree/min) on initial samples (fraction $<0.01 \mathrm{~mm}$ ).

\section{GEOLOGICAL SETTING AND PETROLEUM OCCURRENCE}

The Ukrainian Carpathians represent the central segment of the Carpathian arc (Fig. 1). The Outer Carpathians consist of a number of nappes and folds, made up of the Cretaceous-Paleogene flysch sequence, thrust over the southwestern margin of the East European Platform (Fig. 2).

The Mesozoic-Paleogene strata of the platform basement have been buried to significant depths as a result of the Mio- 


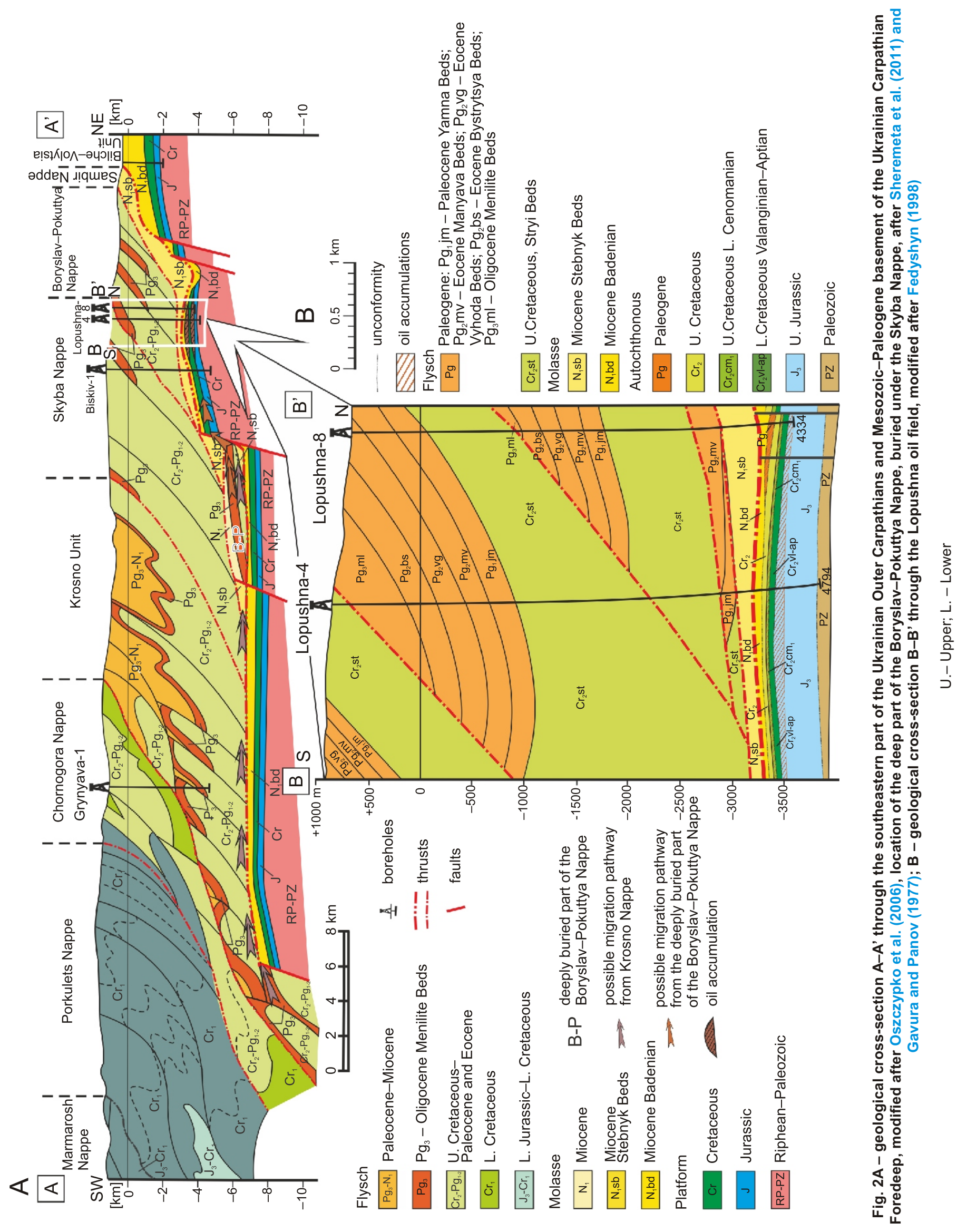


cene overthrusting episode. They often contain suitable structural traps, sealed by Miocene molasse deposits. The Lopushna oil field occurs in the platform basement under the southeastern part of the Ukrainian Carpathian Overthrust near the Ukrainian-Romanian border (Fig. 2). No evident source rocks have been recognized within this succession in the area. Middle Jurassic organic-rich rocks, occurring in the northwestern part of the basement of the Ukrainian Carpathian Foredeep (Koltun et al., 1998), where the Kokhanivka and Orkhovychi oil fields are located, do not exist in its southeastern part, where the Lopushna accumulation has been found. Neocomian-Aptian dark grey argillites, which are penetrated by boreholes in the subthrust sequence in the area of the Lopushna field occurrence, and may spread further under the Carpathian Overthrust, are of small thickness (up to $3.5 \mathrm{~m}$ ) and TOC content (up to 1.6\%) and contain Type III kerogen (Radkovets, $2010,2015)$. The characteristics of these rocks may be assumed to improve further beneath the Carpathian Overthrust, but no data on this exist. Silurian rocks within the study area are overmature (Koltun et al., 1998) and separated from the Mesozoic lithostratigraphic assemblage by a significant stratigraphic unconformity.

Four main structural complexes can be distinguished in the platform basement within the territory of the Lopushna field occurrence: Proterozoic, latest Precambrian to Early Devonian, Mesozoic-Paleogene and Neogene.

Mesozoic deposits include Jurassic and Cretaceous. In the area of the Lopushna field Upper Jurassic strata are represented by about 230 m of Tithonian strata (Rava Ruska Formation) and about 200 m of Kimmeridgian strata (Nyzhniv Formation). Both are made up mainly of limestones and dolomites. Cretaceous strata are represented by its lower part (Neocomian-Aptian clayey-terrigenous deposits) and upper part (Cenomanian to Maastrichtian sandstone and limestone deposits). Upper Cretaceous beds are locally overlain by Paleogene (Eocene) terrigenous strata. The succession described above is covered by the overthrust slab, which comprises folded Miocene molasse of the Sambir Nappe and over $3.5 \mathrm{~km}$ of Cretaceous-Paleogene flysch of the Boryslav-Pokuttya and Skyba Nappes of the Outer Carpathians (Fig. 2).

Oil occurrence has been proven at three lithostratigraphic horizons: Jurassic, Cretaceous and Paleogene (Fig. 2B). Upper Jurassic oil accumulation occurs in the carbonate reservoir rocks of the Nyzhniv Formation. Cretaceous (Albian-Cenomanian) and Paleogene (Eocene) accumulations occur in sandstone reservoirs.

The Lopushna oil accumulation occurs in an anticlinal structure, the size of which on top of the Jurassic strata is $6 \times 3 \mathrm{~km}$ and the magnitude is $150 \mathrm{~m}$. The structure is cut by transverse and longitudinal faults into 7 blocks (Fig. 3). Oil accumulations occur in Jurassic, Cretaceous and Paleogene reservoir rocks in three blocks (Fedyshyn, 1998; Khavenzon et al., 2011).

\section{RESULTS AND DISCUSSION}

\section{LITHOLOGICAL CHARACTERISTICS OF RESERVOIR ROCKS}

The Lopushna structure has been penetrated by 15 boreholes. Oil samples for this study have been taken from the producing boreholes Lopushna-4 and Lopushna-8 (see Fig. 1 for location; Fig. 2, cross-section A-A').

Figure 4 shows sections of these boreholes, which include the age range from Jurassic (Tithonian) to Cretaceous (Lower Cenomanian-Valanginian).

Oil-saturated Upper Albian-Lower Cenomanian sandstones are overlain by Upper Cenomanian Inoceramus lime-

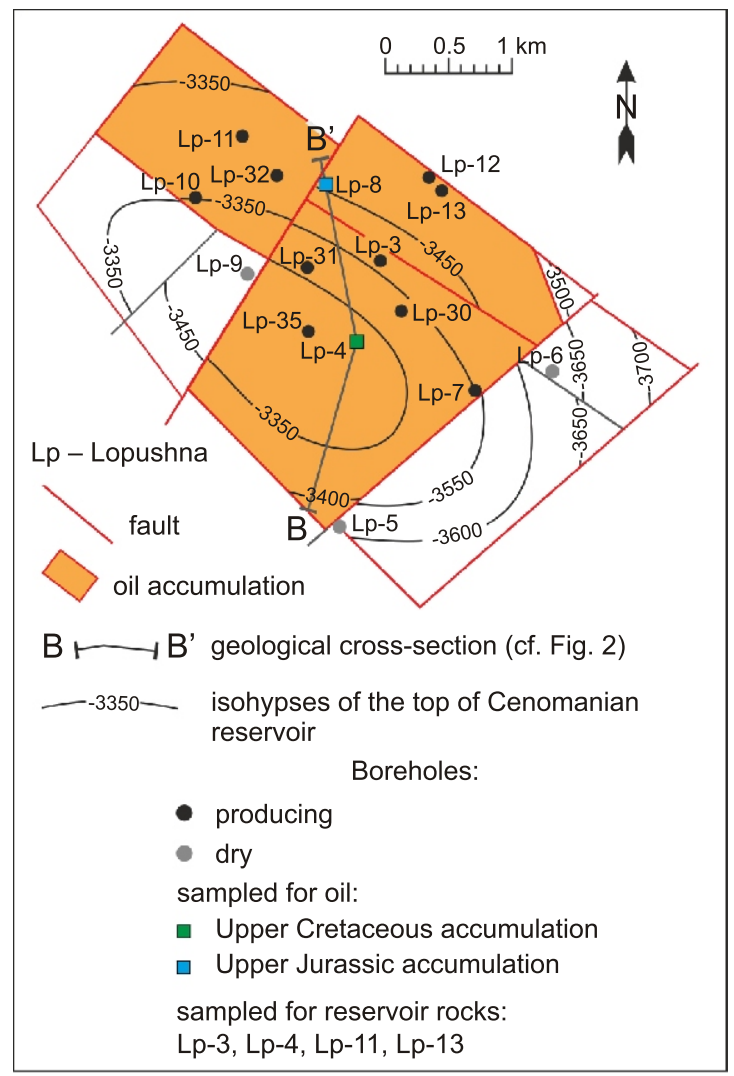

Fig. 3. Structural map of the Lopushna oil field on the top of Cenomanian, modified after Fedyshyn (1998)

stones. The thickness of these sandstones within the Lopushna structure is 15 to $18 \mathrm{~m}$. The sandstones (Fig. 5A, B) are light green and dark green from the presence of glauconite. The rocks are weakly cemented, and medium- and fine-grained. Clastic material is semi-rounded, locally rounded, commonly well-sorted and evenly distributed in the rock. It is represented by quartz grains $(60-80 \%)$, feldspar $(0.1-5 \%)$, and muscovite flakes (0.1-3\%; Table 2). Significant components in the composition of the sandstones are authigenic glauconite (10-20\%), the $0.1-0.5 \mathrm{~mm}$ grains of which are of oval and irregular shape, and phosphate matter (1 to $10 \%)$. The matrix (10-20\%) in the rock is clayey and calcareous. Clays, according to X-ray structure analysis data, are represented by hydromica, and carbonate material by calcite, which is often substituted by dolomite (Radkovets, 1999; Radkovets and Yaremchuk, 2006). The matrix is of contact-porous and contact type. Accessory minerals in sandstones, zircon and epidote, are observed sporadically. Ore minerals are represented by pyrite (up to $3 \%$ ) and solitary grains of ilmenite. Oil in the sandstone in the shape of irregular spots $0.5-1.5 \mathrm{~mm}$ in size that fill the space between the quartz grains. Sandstone reservoir rocks in the Lopushna field have good reservoir properties. Porosity ranges from 9.2 to $16 \%$ and permeability is $0.7 \mathrm{mD}$ (Fedyshyn, 1998).

Jurassic oil accumulation occurs in organogenic-detrital limestones of Tithonian age. Within the Lopushna structure the total thickness of these limestones is 150-200 m (Gavrylyshyn, 1998), a large part of which (up to $83 \mathrm{~m}$ ) is oil saturated. The limestones are overlain by Lower Cretaceous tight terrigenous-clayey strata with a maximum thickness of $70 \mathrm{~m}$.

Organogenic-detrital limestones (Fig. 5B) are grey and light grey in colour. They are hard, tight, in places cavernous. Calcite content in limestones ranges from 60 to $75 \%$, and commonly is substituted by dolomite, the content of which reaches $25 \%$ of the rock. The clay content of the rocks makes up $10-15 \%$. 


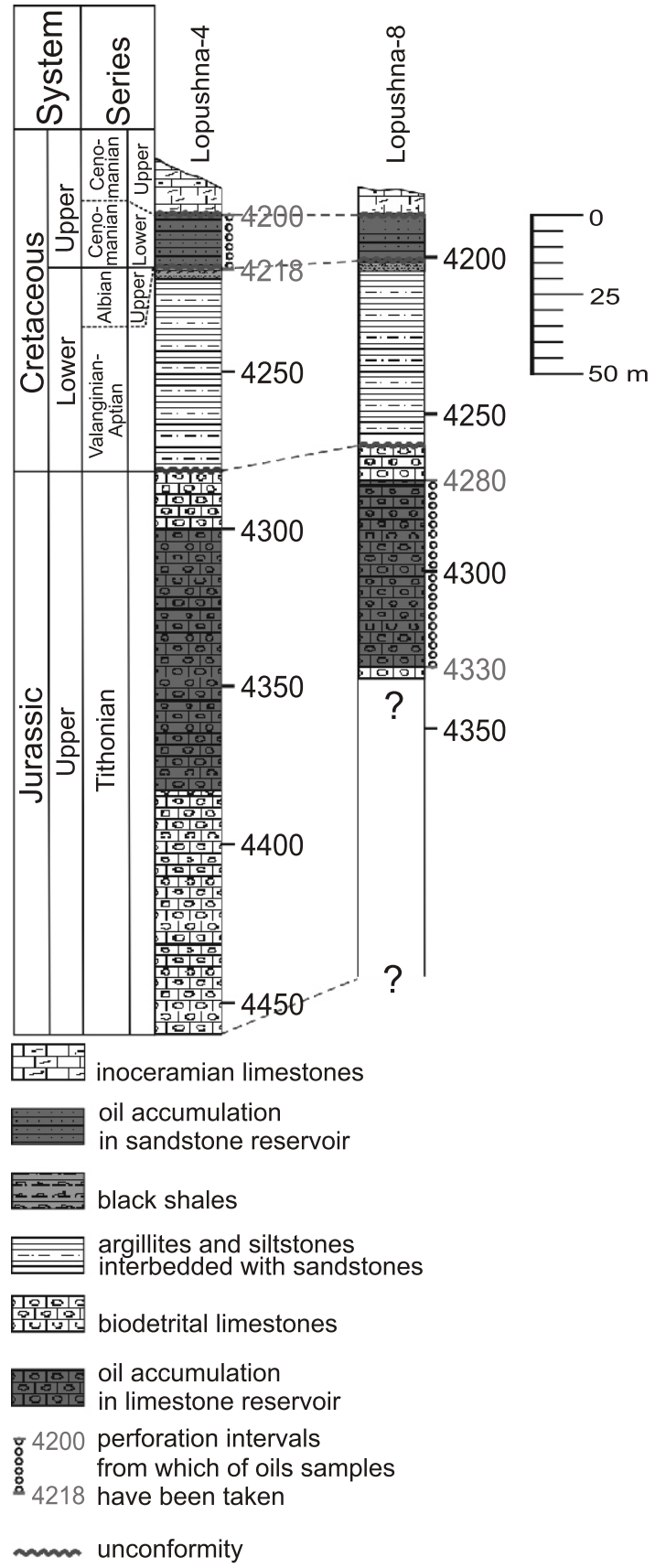

Fig. 4. Lithological sections of boreholes Lopushna-4 and -8 (see Figs. 1, 2 and 3 for location), oil-saturated depth ranges after Fedyshyn (1998)

The limestones are made up of fine-grained carbonate material and bioclasts of various size. The limestones are recrystallised dolomitised, which has resulted in a reduction of rock volume and the formation of pores (0.2-0.5 mm across), filled with oil. Limestone reservoir rocks in the Lopushna field have good reservoir properties. Porosity ranges from 11 to $14.3 \%$ and permeability is $0.7 \mathrm{mD}$ (Fedyshyn, 1998).

\section{GEOCHEMICAL CHARACTERISTICS OF OILS} AND OIL-OIL CORRELATION

In order to identify the origin of oil from the Lopushna field, geochemical data from the oil samples studied have been compared with results already obtained from oils and source rocks from two existing petroleum systems in the area of the Ukrai-
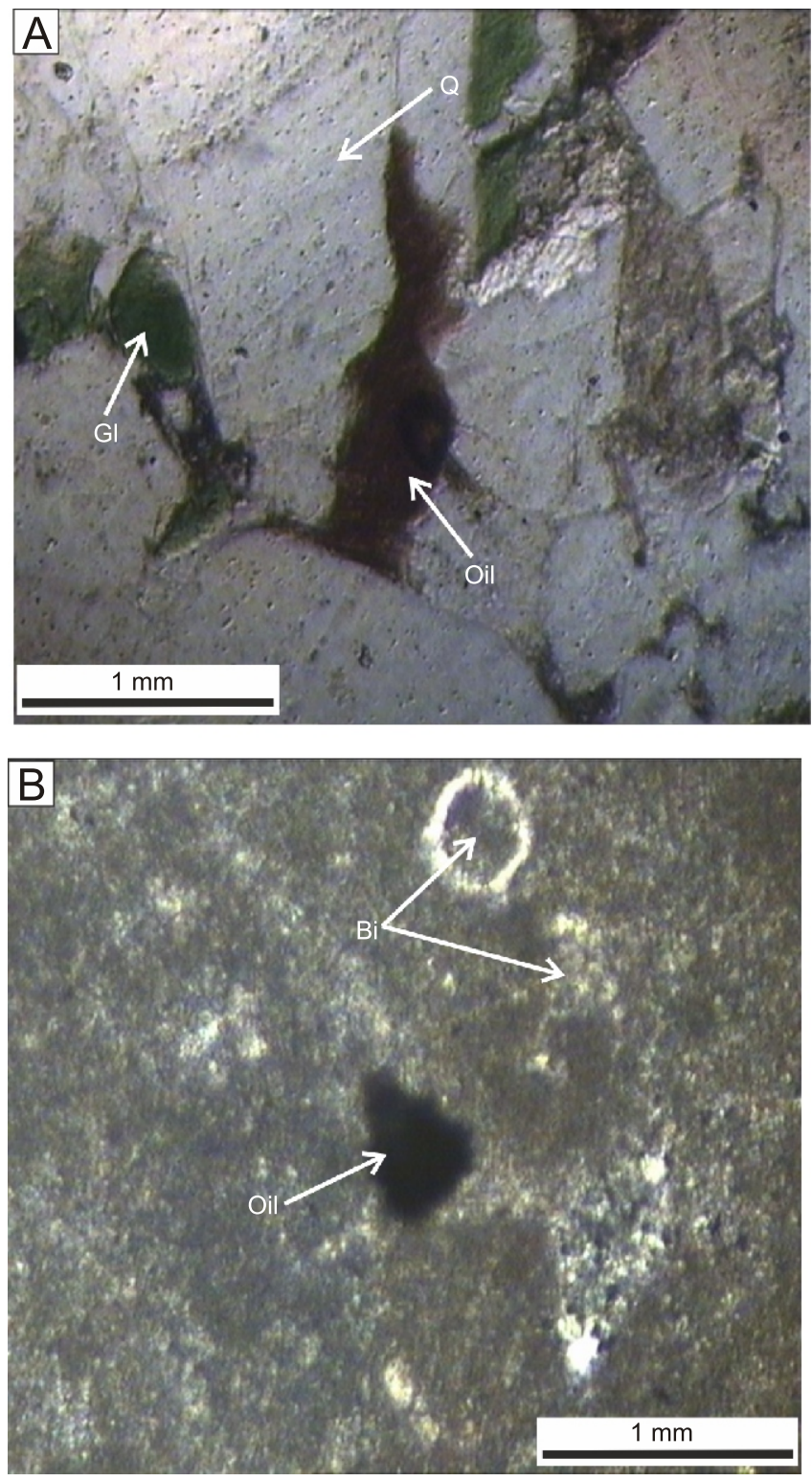

Fig. 5. Photomicrographs of reservoir rocks from the Lopushna oil field

A - oil-saturated sandstone from borehole Lopushna-4, depth interval 4210.7: Q - quartz; GI - glauconite; Oil - oil in the intergranular space; B - oil-saturated limestone from the Lopushna-4 borehole, depth interval 4360-4368: $\mathrm{Bi}$ - problematic bioclasts, Oil - oil in cavities

nian Carpathians, namely the petroleum systems of the Outer Carpathians and of the platform deposits of the basement of the Ukrainian Carpathian Foredeep (Koltun, 1992; Koltun et al., 1998; Kotarba et al., 2005, 2007; Kotarba and Koltun, 2006; Więcław et al., 2012).

All oils from the Lopushna boreholes are characterized by the dominance of short-chain hydrocarbons. In the crude oil from the Lopushna- 4 borehole the toluene content is greater than that of heptadecane and there is a bimodal distribution of $n$-alkanes (Fig. 6). The whole-oil GC analysis of the oils indicated that oils from the Lopushna field have not undergone extensive secondary processes.

TR1 to TR8 ratios (Halpern, 1995) correlate with those of the less biodegraded oils from the Carpathian flysch strata (Table 3 and Fig. 7). The values of the $n$-heptane/methylcyclohexane ratio (Table 4 and Fig. 8) are 0.80 and 0.82 . The latter in combination with the 1.24 value of the toluene/n-heptane ratio indicates 

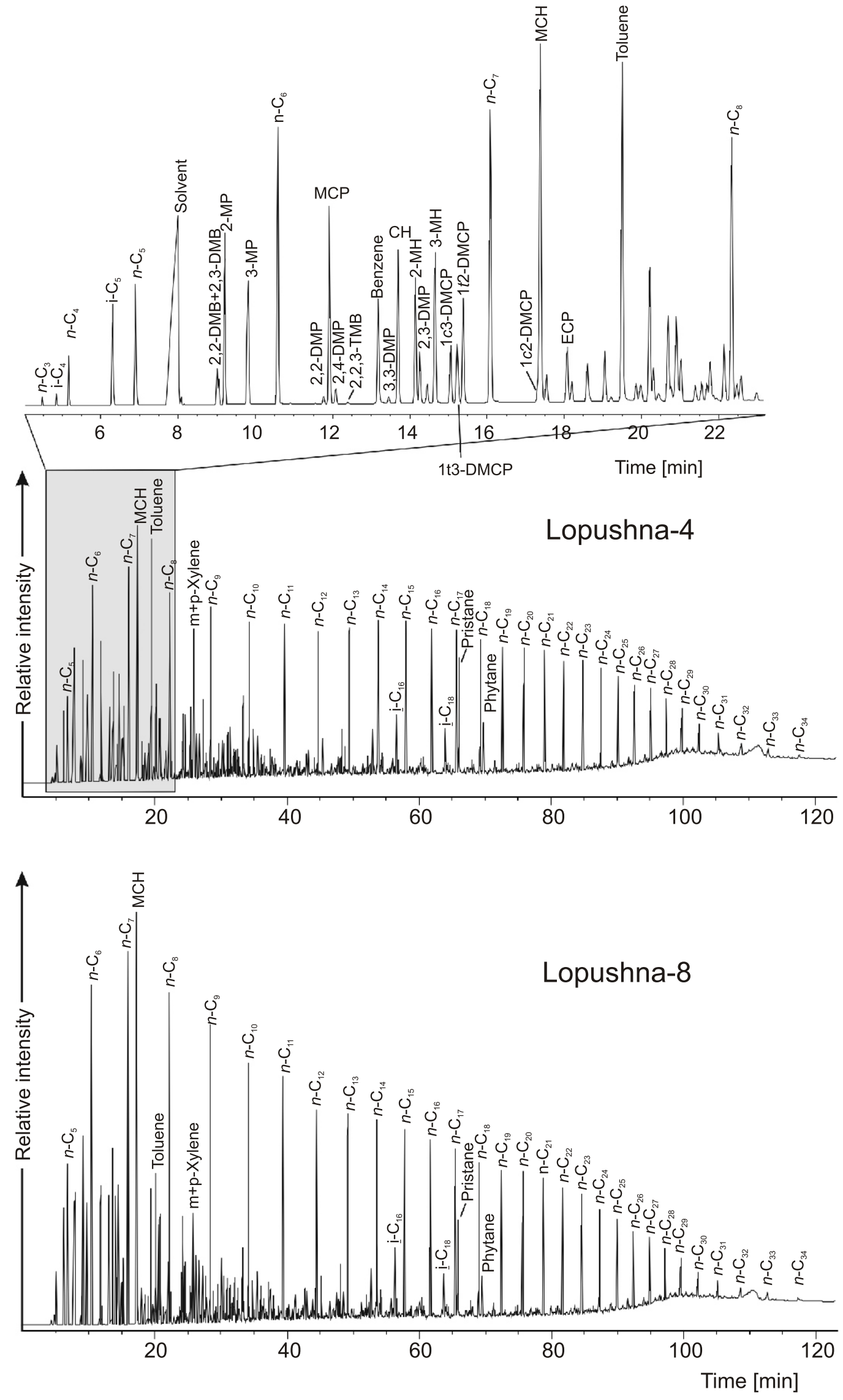

Fig. 6. High-resolution gas chromatogram of crude oils Lopushna-4 and -8 with optimized gas chromatographic separation of $\mathrm{C}_{7}$ hydrocarbons (top)

Numbers refer to carbon atoms in $n$-alkane chain, $\mathrm{CH}$ - cyclohexane, DMB - dimethylbutane, DMCP dimethylcyclopentane, DMP - dimethylpentane, ECP - ethylcyclopentane, $\mathrm{MCH}$ - methylcyclohexane, $\mathrm{MH}$ methylhexane, MCP - methylcyclopentane, MP - methylpentane, TMB - trimethylbutane, $m$ - meta, $p$ - para 
Indices calculated based on whole-oil GC analysis

\begin{tabular}{|c|c|c|c|c|c|c|c|c|c|c|c|c|c|c|}
\hline $\begin{array}{l}\text { Sample } \\
\text { code }\end{array}$ & Reservoir age & $\begin{array}{c}\text { Toluene/ } \\
n-\mathrm{C}_{7} \mathrm{H}_{16}\end{array}$ & $\begin{array}{c}n-\mathrm{C}_{7} \mathrm{H}_{16} / \\
\mathrm{MCH}\end{array}$ & HR & $\mathrm{HHI}$ & $\underset{\mathrm{MCH}}{\mathrm{CH} /}$ & IHR & $\begin{array}{l}n-7 \mathrm{H}_{16} \\
/ 2-\mathrm{MH}\end{array}$ & $\begin{array}{c}\mathrm{m}-+\mathrm{o}-+\mathrm{p}- \\
\text { xylene/n- } \mathrm{C}_{8} \mathrm{H}_{18}\end{array}$ & $\begin{array}{c}\text { Temp } \\
{\left[{ }^{\circ} \mathrm{C}\right]}\end{array}$ & $\mathrm{CPI}_{17-23}$ & $\mathrm{Pr} / \mathrm{Ph}$ & $\begin{array}{c}\mathrm{Pr} / \\
n-\mathrm{C}_{17}\end{array}$ & $\begin{array}{c}\mathrm{Ph} / \\
n-\mathrm{C}_{18}\end{array}$ \\
\hline Lp-4 & U.Cretaceous & 1.24 & 0.80 & 23.1 & 1.02 & 0.38 & 1.14 & 2.52 & 1.33 & 122 & 1.05 & 2.26 & 0.99 & 0.47 \\
\hline Lp-8 & U.Jurassic & 0.41 & 0.82 & 29.1 & 1.08 & 0.38 & 1.63 & 2.98 & 0.62 & 126 & 1.05 & 2.33 & 0.70 & 0.32 \\
\hline
\end{tabular}

U. - Upper; $\mathrm{MCH}-$ methylcyclohexane; $\mathrm{HR}$ (heptane ratio) $=100 \times n-\mathrm{C}_{7} \mathrm{H}_{16} / \mathrm{S}\left(\mathrm{CH}+\mathrm{C}_{7} \mathrm{HCs}\right): \mathrm{CH}-$ cyclohexane; $\mathrm{HCs}-$ hydrocarbons; $\mathrm{HHI}=n-\mathrm{C}_{6} \mathrm{H}_{14}$ $+n-\mathrm{C}_{7} \mathrm{H}_{16} /(\mathrm{CH}+\mathrm{MCH}) ; \mathrm{IHR}$ (isoheptane ratio) $=(2-+3-\mathrm{MH}) /(1 c 3-+1$ t3- + 1t2-DMCP): MH - methylhexane; DMCP - dimethylcyclopentane; Temp $=140+15[\ln (2,4-\mathrm{DMP} / 2,3-\mathrm{DMP})]$ (Mango, 1997): DMP - dimethylpentane; $\mathrm{CPI}_{17-23}=\left[\left(\mathrm{C}_{17}+\mathrm{C}_{19}+\mathrm{C}_{21}\right)+\left(\mathrm{C}_{19}+\mathrm{C}_{21}+\mathrm{C}_{23}\right)\right] /\left[2^{*}\left(\mathrm{C}_{18}+\mathrm{C}_{20}+\mathrm{C}_{22}\right)\right] ; \mathrm{Pr}-$ pristane; $\mathrm{Ph}$ - pytane; for other explanations see Table 1

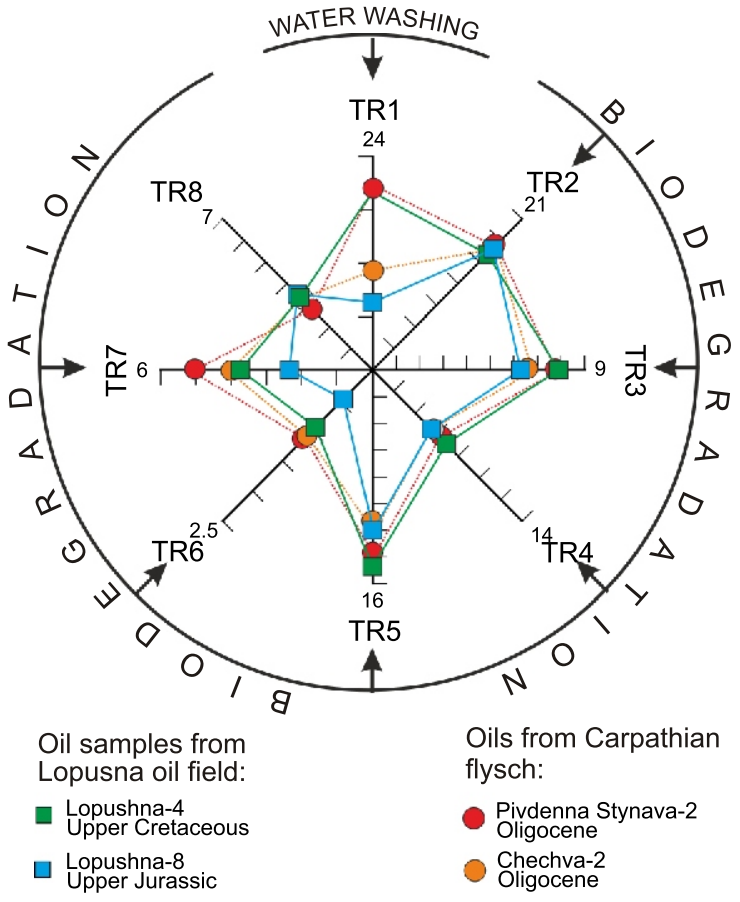

Fig. 7. Star diagram of $\mathrm{C}_{7}$ oil transformation ratios

evaporative fractionation processes in the Cretaceous oil accumulation (Thompson, 1987). Low values of pristane $/ n-\mathrm{C}_{17} \mathrm{H}_{36}$ and phytane $/ n-\mathrm{C}_{18} \mathrm{H}_{38}$ ratios (Table 4 ), reflecting the low concentrations of isoprenoids in relation to $n$-alkanes, show that the oils did not undergo any significant biodegradation. For both oil samples the distribution of $n$-alkanes and isoprenoids (Fig. 6), their ratios calculated based on the distribution of short-chain hydrocarbons, and values of hydrocarbon indices (Tables 3 and 4) do not indi-

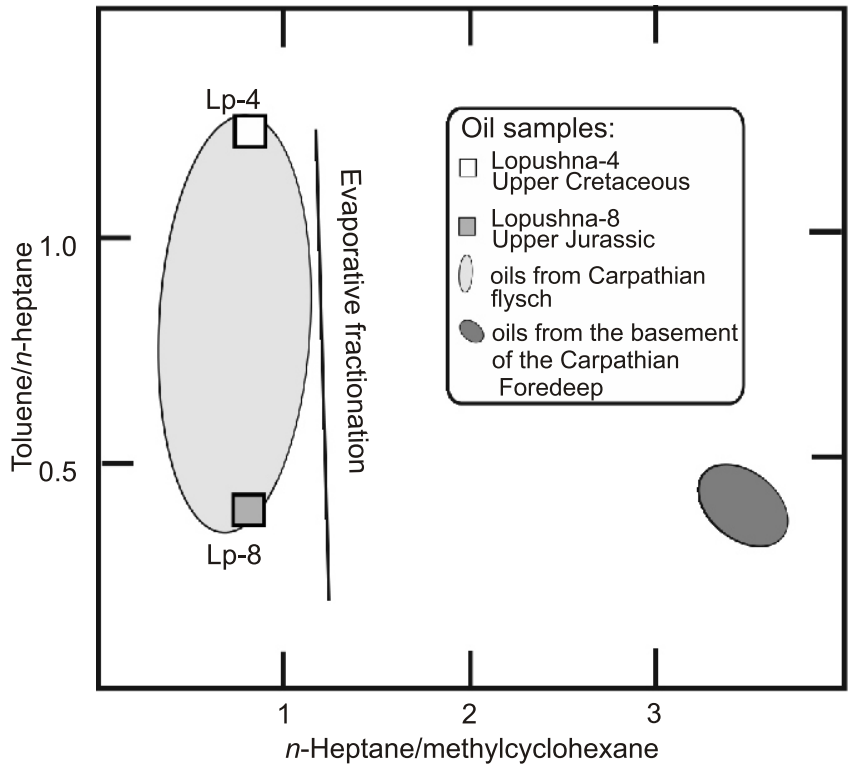

Fig. 8. Toluene/n-heptane ratio versus $n$-heptane/methylcyclohexane ratio

Scheme after Thompson (1987)

cate any significant secondary processes. No characteristic "hump" of an unresolved complex mixture (Peters et al., 2005) is observed in chromatograms (Fig. 6).

The present-day reservoir temperature in the Lopushna field is $106^{\circ} \mathrm{C}$ at a depth of $4200 \mathrm{~m}$ in the Albian-Cenomanian accumulation and $109^{\circ} \mathrm{C}$ at a depth of $4300 \mathrm{~m}$ in the Upper Jurassic accumulation. The post-depositional burial history of the Mesozoic and Paleogene deposits of the study area is related to the Carpathian overthrusting episode in the Miocene and consequently these oil-bearing rocks, as well as the overlying flysch sequence (Koltun et al., 1998), most likely have now

Values of Halpern (1995) C7 ratios

\begin{tabular}{|c|c|c|c|c|c|c|c|c|c|c|c|c|c|}
\hline $\begin{array}{l}\text { Sample } \\
\text { code }\end{array}$ & Reservoir age & TR1 & TR2 & TR3 & TR4 & TR5 & TR6 & TR7 & TR8 & $\mathrm{C} 1$ & $\mathrm{C} 2$ & C3 & $\mathrm{C} 4$ \\
\hline Lp-4 & Upper Cretaceous & 20.0 & 16.2 & 7.86 & 6.41 & 14.3 & 0.84 & 3.76 & 3.39 & 0.02 & 0.63 & 01.8 & 0.10 \\
\hline Lp-8 & Upper Jurassic & 6.93 & 17.0 & 6.27 & 5.71 & 12.0 & 0.46 & 2.34 & 3.56 & 0.02 & 0.62 & 0.24 & 0.06 \\
\hline
\end{tabular}

U. - Upper; TR1 = toluene/1,1-DMCP: DMCP - dimethylcyclopentane; TR2 = $n$ - $\mathrm{C}_{7} \mathrm{H} 16 / 1,1-\mathrm{DMCP} ;$ TR3 = 3-methylhexane/1,1-DMCP; TR4 = 2-methylhexane/1,1-DMCP; TR5 = P2/1,1-DMCP: P2 = 2-methylhexane + 3-methylhexane; TR6 = 1c2-DMCP/1,1-DMCP; TR7 = 1t3-DMCP/1,1-DMCP; TR8 = P2/P3: P3 = 2,2-dimethylpentane + 2,3-dimethylpentane + 2,4-dimethylpentane + 3,3-dimethylpentane + 3-ethylpentane; $C 1$ = 2,2-dimethylpentane/P3; C2 = 2,3-dimethylpentane/P3; C3 = 2,4-dimethylpentane/P3; C4 = 3,3-dimethylpentane/P3; for other explanations see Table 1 


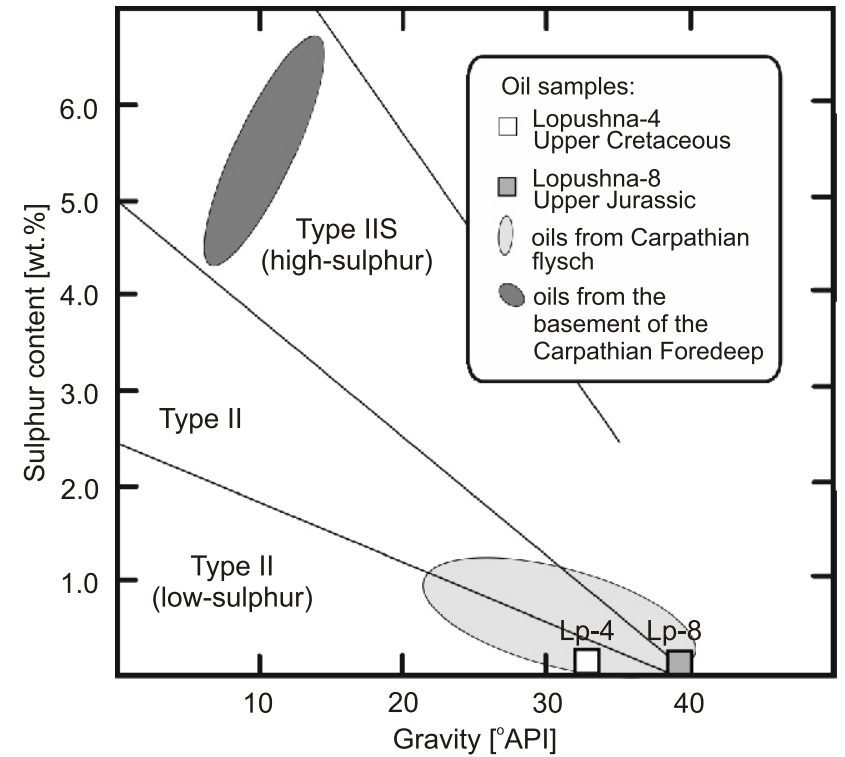

Fig. 9. Sulphur content versus gravity

Classification of source kerogen type by Orr (2001)

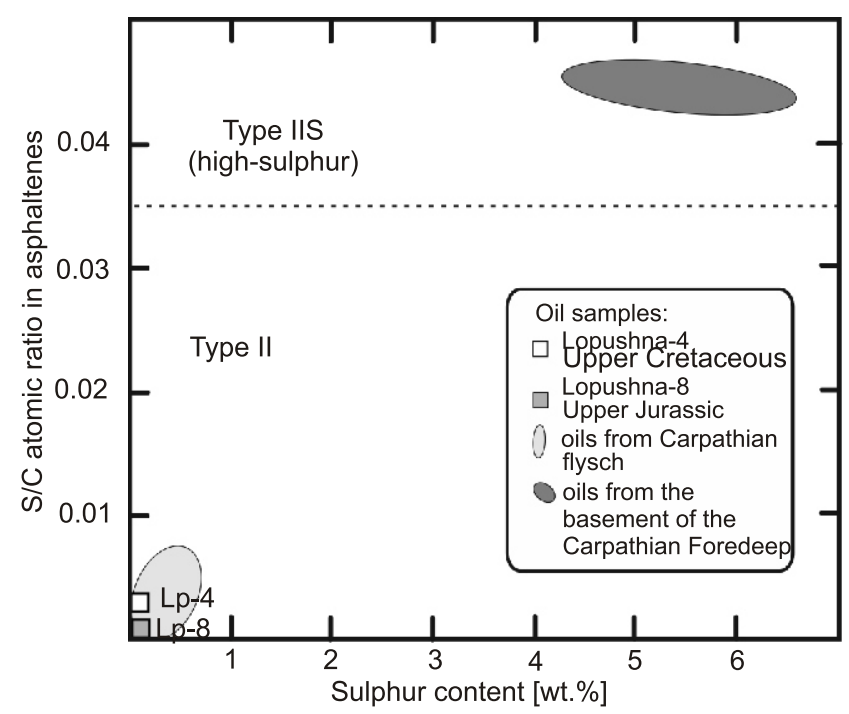

Fig. 10. S/C atomic ratio in asphaltenes versus sulphur content in oils

Classification of source kerogen type by Orr (1986)

reached their maximum maturation level, and hence have never undergone thermal cracking, which can occur at temperatures in the range of $150-175^{\circ} \mathrm{C}$ (Claypool and Mancini, 1989).

Oils from the Lopushna field are characterized by specific gravities of 33.1 and $39.6 \mathrm{API}$ and sulphur contents of 0.12 and 0.03 wt. \%, respectively (Table 1 ). The values of these parameters fully correspond to the ones of the oils from the Carpathian flysch sequence (Kotarba et al., 2005, 2007), while oils from the basement of the Carpathian Foredeep show quite different values (Fig. 9). The crude oils analysed from the Lopushna field are low in sulphur, suggesting a low- and normal-sulphur Type II kerogen in their potential source rocks (Orr, 1986, 2001), and deposition in a clastic environment (Moldowan et al., 1985).

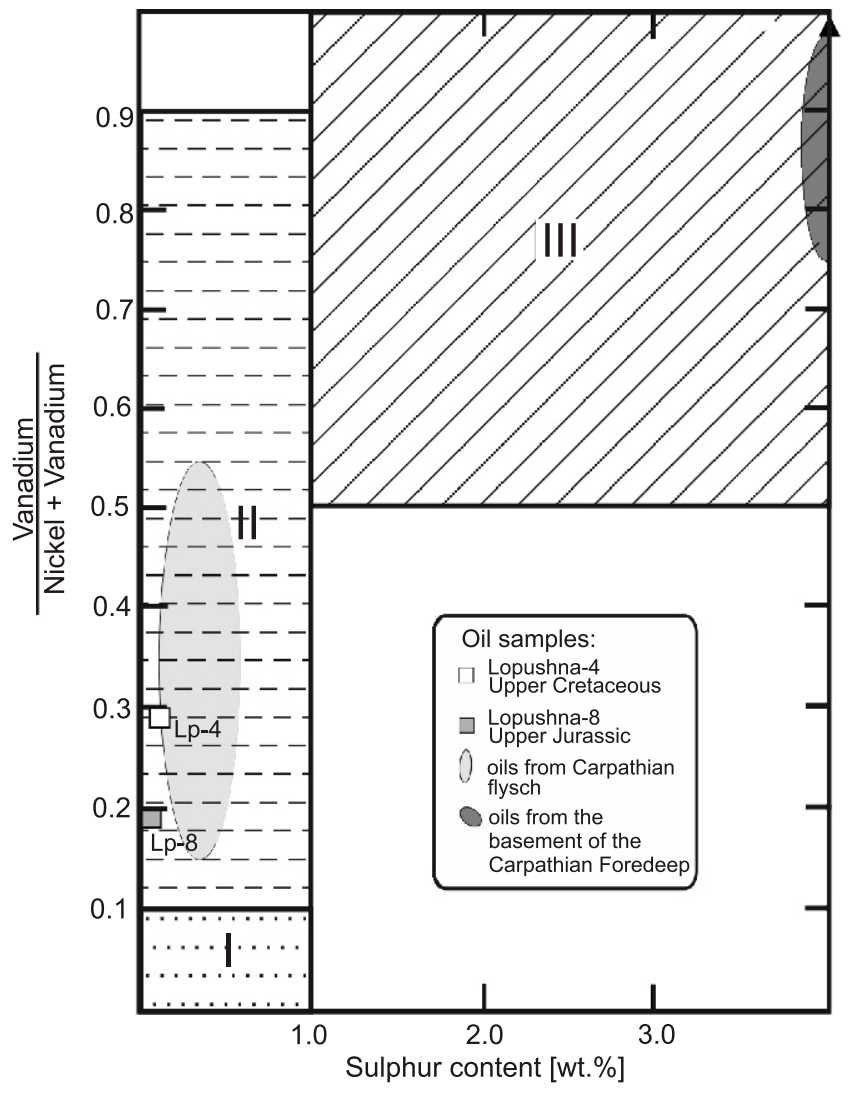

Fig. 11. $\mathrm{V} /(\mathrm{V}+\mathrm{Ni})$ ratio versus sulphur content in oils

Classification of source kerogen sedimentation conditions after Lewan (1984)

The results of elemental analysis of asphaltenes precipitated from these oils confirm this statement (Table 1 and Fig. 10). Low values of the S/C atomic ratio in asphaltenes also indicate that these oils have been generated from low-sulphur Type II kerogen. The vanadium and nickel contents also support these conclusions (Table 1 and Fig. 11). The oils under study were generated from organic matter deposited in conditions in which nickel and vanadium ions were available, namely in marine and deltaic facies (Type II and III kerogens; regime II in Lewan, 1984). As is evident from Figures 10 and 11, by the values of the S/C atomic ratio in asphaltenes and vanadium and nickel contents, oils from the Lopushna field correlate well with the oils from the Carpathian flysch sequence, differing substantially from the oils from the basement of the Ukrainian Carpathian Foredeep (Kotarba et al., 2007; Więcław et al., 2012).

Distributions of $n$-alkanes and isoprenoids in the crude oils analysed show a maximum in the short-chain hydrocarbons range (Fig. 6), characteristic of hydrocarbons generated from marine organic matter (e.g., Peters et al., 2005). In both oils the $\mathrm{CPI}$ values are $>1.0$, indicating a clastic environment of source organic matter deposition (Moldowan et al., 1985). Pristane/phytane ratios greatly exceeding one (Table 4) support this statement, indicating suboxic environments during the deposition of source rock (Didyk et al., 1978). This inference is supported by the correlation between pristane $/ n-\mathrm{C}_{17} \mathrm{H}_{36}$ and phytane $/ n-\mathrm{C}_{18} \mathrm{H}_{38}$ indices (Fig. 12) and dibenzotiophene/phenantrene and pristane/phytane ratios (Fig. 13), which for the oils under study fully fits the trend indicated for the oils accumulated in the Carpathian flysch sequence. 


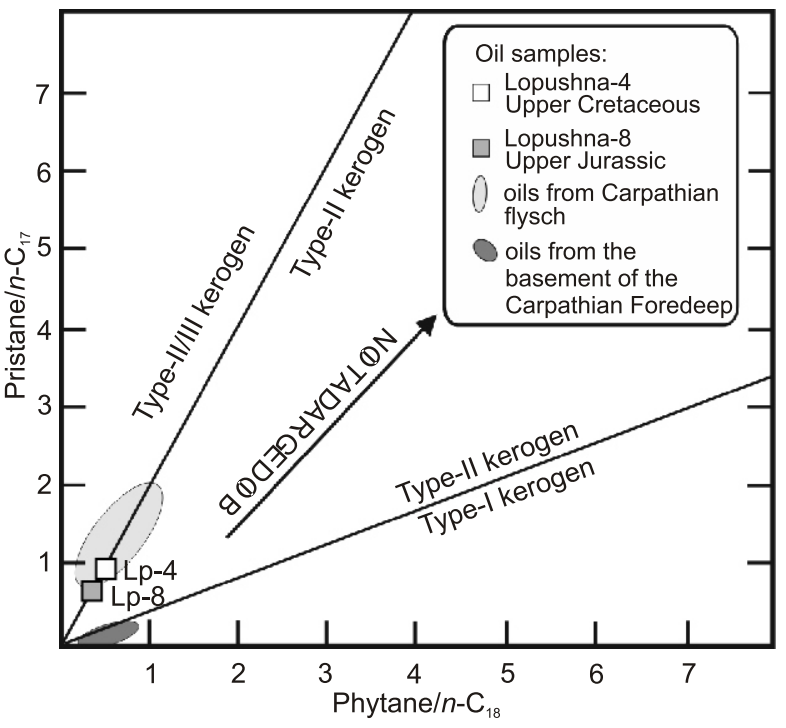

Fig. 12. Genetic characterization of oils in terms

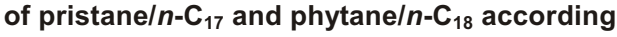
to the categories of Obermajer et al. (1999)

As evident from Figures 12 and 13, the oils from the basement of the Carpathian Foredeep show quite different characteristics. A similar distribution of regular $\alpha \alpha \alpha$ steranes in the Lopushna crude oils with those for the oils from the Carpathian flysch sequence and the presence of a highly specific type of pentacyclic triterpane, i.e., oleanane (Table 5) which is always present in oils, within the Carpathian flysch sequence (Kotarba et al., 2007; Więcław et al., 2012), suggests that they belong to the same family.

The biomarker data reported above are supported by the stable carbon isotope composition of the crude oils and their individual fractions (Table 1 and Fig. 14). Oils and their individual fractions from the two Lopushna reservoirs show similar isotopic data. The depletion of asphaltenes in the ${ }^{13} \mathrm{C}$ isotope relative to resins in oil from the Lopushna-4 borehole is evidence of oil generated from algal kerogen (Galimov, 1973, 1986). Figure 14 allows comparison of isotopic data from the Lopushna oils with oils from two families of the Ukrainian Carpathian region. Correlation with oils accumulated in the Carpathian flysch sequence is evident, while oils from the basement of the Carpathian Foredeep show quite different results.

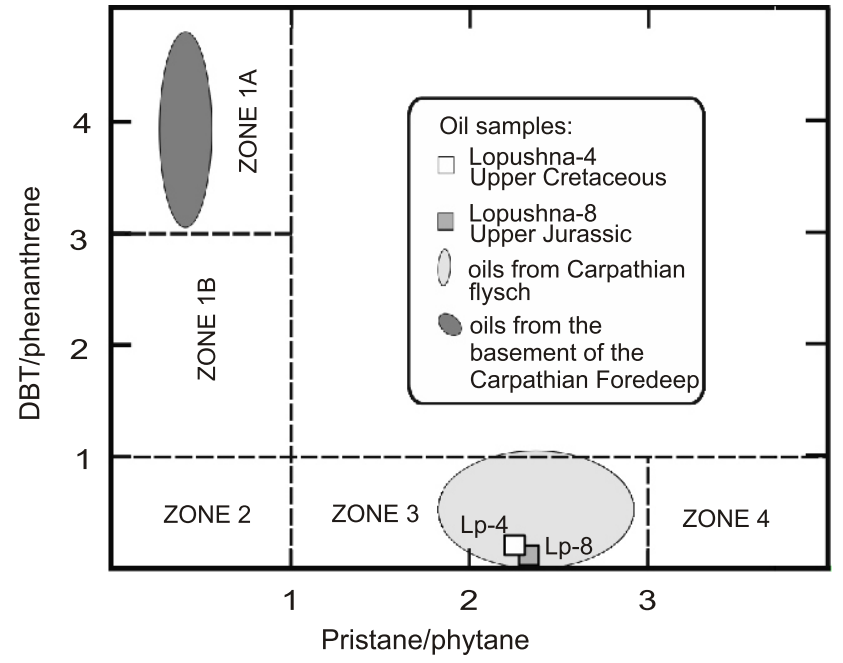

Fig. 13. A cross-plot of the dibenzotiophene/phenantrene ratio versus the pristane/phytane ratio

Classification of deposition conditions after Hughes et al. (1995); Zone $1 \mathrm{~A}$ - marine carbonate; Zone $1 \mathrm{~B}$ - marine carbonate or marine or lacustrine sulphate-rich marl; Zone 2 - lacustrine sulphate-poor; Zone 3 - marine shale and other lacustrine; Zone 4 - fluvial/deltaic

The complex geochemical characteristics of crude oils from the Lopushna field discussed above, including biomarker and stable carbon isotopic data, show a clear correlation of these oils with those accumulated in the Carpathian flysch sequence and represent enough evidence to attribute them to the same oil family. Their apparent difference from all geochemical indices in from the oils from the basement of the Carpathian Foredeep (Kokhanivka and Orkhovychi fields), which belong to another oil family, as well as from oils accumulated in the autochthonous Miocene strata of the Carpathian Foredeep and its Paleozoic-Mesozoic and basement at the Polish territory (Więcław, 2011), supports this conclusion.

\section{MATURITY}

The maturity of the crude oils was determined based on light hydrocarbons (Table 4), selected biomarkers (Table 5), and indices deriving from relative concentrations of phenanthrene and dibenzothiophene and their methyl derivative distributions (Table 6).

Selected biomarker characteristics of oils

\begin{tabular}{|c|c|c|c|c|c|c|c|c|c|c|c|c|c|c|c|c|c|}
\hline \multirow{2}{*}{$\begin{array}{c}\text { Sample } \\
\text { code }\end{array}$} & \multirow{2}{*}{$\begin{array}{l}\text { Reservoir } \\
\text { age }\end{array}$} & \multirow{2}{*}{$\begin{array}{c}\mathrm{S} / \\
(\mathrm{S}+\mathrm{T})\end{array}$} & \multirow{2}{*}{$\begin{array}{l}\text { Bis/ } \\
\text { Hop }\end{array}$} & \multirow{2}{*}{$\begin{array}{l}\mathrm{C}_{27} \text { dia/ } \\
\mathrm{C}_{27} \text { reg. }\end{array}$} & $\mathrm{C}_{27}$ & $\mathrm{C}_{28}$ & $\mathrm{C}_{29}$ & \multirow{2}{*}{$\begin{array}{l}\mathrm{Ol} / \\
\mathrm{Hop}\end{array}$} & \multirow{2}{*}{$\begin{array}{l}\text { Mor/ } \\
\text { Hop }\end{array}$} & \multirow{2}{*}{$\begin{array}{c}\mathrm{H}_{31} \\
\mathrm{~S} /(\mathrm{S}+\mathrm{R}) \\
\end{array}$} & \multirow[t]{2}{*}{$\mathrm{C}_{29} \mathrm{SR}$} & \multirow{2}{*}{$\begin{array}{c}\mathrm{C}_{29} / \\
\mathrm{C}_{27 \text { ster }}\end{array}$} & \multirow{2}{*}{$\begin{array}{l}\text { Ts/ } \\
\text { Tm }\end{array}$} & \multirow{2}{*}{$\begin{array}{c}\mathrm{TA}(\mathrm{I}) / \\
\mathrm{TA}(\mathrm{I}+\mathrm{II})\end{array}$} & \multirow{2}{*}{$\begin{array}{l}\text { Dia/ } \\
\text { Reg }\end{array}$} & \multirow{2}{*}{$\begin{array}{l}\mathrm{C}_{29} / \\
\text { Hop }\end{array}$} & \multirow[t]{2}{*}{$\begin{array}{l}\mathrm{C}_{35} / \\
\mathrm{C}_{34}\end{array}$} \\
\hline & & & & & & [\%] & & & & & & & & & & & \\
\hline Lp-4 & & 0.38 & - & & 36 & 26 & 38 & 0.11 & 0.28 & & & 1.07 & 0.65 & n.d. & 0.27 & 0.53 & 1.06 \\
\hline Lp-8 & & & - & & 40 & 27 & 33 & 0.14 & 0.23 & 0.56 & & 0.84 & 0.80 & n.d. & 1.19 & 0.59 & 0.86 \\
\hline
\end{tabular}

$\mathrm{S} /(\mathrm{S}+\mathrm{T})=$ all steranes/(all steranes + all terpanes); Bis/Hop $=28,30$-bisnorhopane $/ 17 \alpha$ hopane; $\mathrm{C}_{27}$ dia/ $\mathrm{C}_{27}$ reg. $=\mathrm{C}_{27} \beta \alpha 20 \mathrm{~S}$ diasterane $/ \mathrm{C}_{27} \alpha \alpha \alpha 20 \mathrm{R}$ sterane; $\mathrm{C}_{27}=\mathrm{C}_{27} \alpha \alpha \alpha 20 \mathrm{R}$ sterane/($\left(\mathrm{C}_{27}+\mathrm{C}_{28}+\mathrm{C}_{29}\right) \alpha \alpha \alpha 20 \mathrm{R}$ steranes*100; $\mathrm{C}_{28}=\mathrm{C}_{28} \alpha \alpha \alpha 20 \mathrm{R}$ sterane $/\left(\mathrm{C}_{27}+\mathrm{C}_{28}+\mathrm{C}_{29}\right) \alpha \alpha \alpha 20 \mathrm{R}$ steranes*100; $\mathrm{C}_{29}=\mathrm{C}_{29}$ $\alpha \alpha \alpha 20 R$ sterane/ $\left(\mathrm{C}_{27}+\mathrm{C}_{28}+\mathrm{C}_{29}\right) \alpha \alpha \alpha 20 \mathrm{R}$ steranes*100; Ol/Hop = oleanane/17 $\alpha$ hopane; Mor/Hop = moretane/17 $\alpha$ hopane; $\mathrm{H}_{31} \mathrm{~S} /(\mathrm{S}+\mathrm{R})=\mathrm{homohopane}$ $22 \mathrm{~S} /(22 \mathrm{~S}+22 \mathrm{R}) ; \mathrm{C}_{29} \mathrm{SR}=$ epimerisation of regular steranes $\mathrm{C}_{29}$ ratio; $\mathrm{C}_{29} / \mathrm{C}_{27 \text { ster }}=\mathrm{C}_{29}$ norhopane $/ \mathrm{C}_{27} \alpha \alpha \alpha 20 \mathrm{R}$ sterane; Ts/Tm $=\mathrm{C}_{27} 18 \alpha$ trisnorhopane $/ \mathrm{C}_{27} 17 \alpha$ trisnorhopane, $\mathrm{TA}(\mathrm{I}) / \mathrm{TA}(\mathrm{I}+\mathrm{II})=\left(\mathrm{C}_{21}+\mathrm{C}_{22}\right.$ triaromatic $) /\left(\mathrm{C}_{21}+\mathrm{C}_{22}+\mathrm{C}_{26-28}\right.$ triaromatic steroids $) ;$ Dia/Reg $=\mathrm{C}_{27} \beta \alpha 20 \mathrm{~S}$ diasterane $/ \mathrm{C}_{29}$ $\alpha \alpha \alpha 20 R$ sterane, $C_{29} / \mathrm{Hop}=\mathrm{C}_{29}$ norhopane $/ 17 \alpha$ hopane; $\mathrm{C}_{35} / \mathrm{C}_{34}=\mathrm{C}_{35}(22 \mathrm{~S}+22 \mathrm{R})$ homohopanes $/ \mathrm{C}_{34}(22 \mathrm{~S}+22 \mathrm{R})$ homohopanes; n.d. - not determined; for other explanation see Table 1 


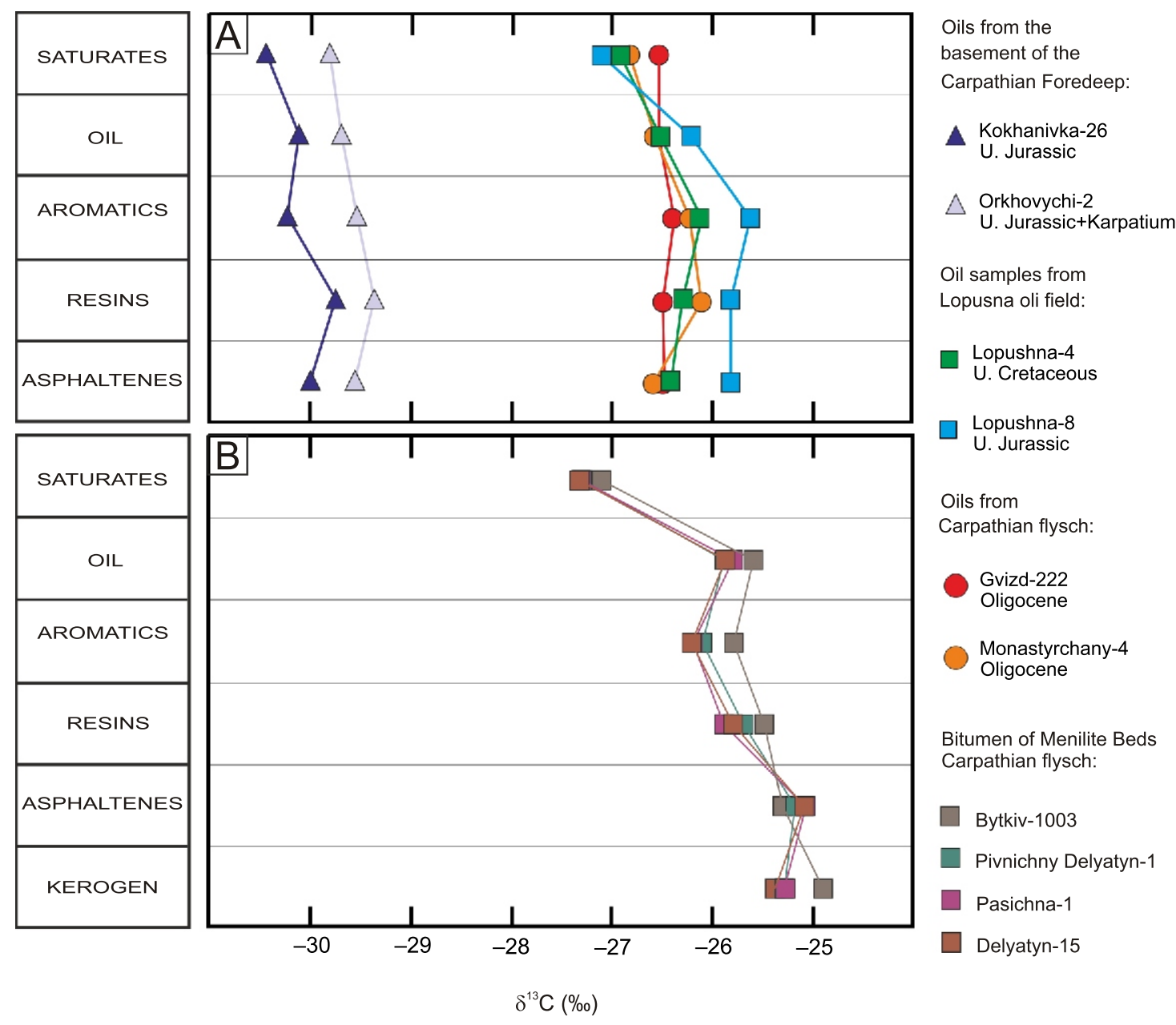

Fig. 14. Stable carbon isotope composition of (A) crude oils and their individual fractions from the Lopushna field, from the Outer Carpathian strata and from the Mesozoic basement of the Ukrainian Carpathian Foredeep and $(B)$ bitumen, their individual fractions and kerogen of the Menilite Beds from the Boryslav-Pokuttya Unit (Kotarba et al., 2005)

See Figure 1 for location

Table 6

Indices calculated based on distribution of phenantrene and dibenzotiophene and their derivatives

\begin{tabular}{|l|c|c|c|c|c|c|c|c|c|c|}
\hline $\begin{array}{c}\text { Sample } \\
\text { code }\end{array}$ & $\begin{array}{c}\text { Reservoir } \\
\text { age }\end{array}$ & MPI1 & MPR & MPR1 & $\begin{array}{c}\mathrm{R}_{\text {cal }} \\
{[\%]}\end{array}$ & $\begin{array}{c}\mathrm{R}_{\text {calmpR }} \\
{[\%]}\end{array}$ & DBT/P & MDR & $\begin{array}{c}\mathrm{R}_{\text {cal(DBT) }}[\%] \\
{[\%]}\end{array}$ & $\begin{array}{c}\mathrm{T}_{\max (\mathrm{DBT})} \\
\left.\left[{ }^{\circ} \mathrm{C}\right)\right]\end{array}$ \\
\hline Lp-4 & Upper Cretaceous & 0.74 & 0.79 & 0.43 & 0.82 & 0.80 & 0.2 & 2.3 & 0.7 & 435 \\
\hline Lp-8 & Upper Jurassic & 0.68 & 0.72 & 0.38 & 0.78 & 0.70 & 0.1 & 5.7 & 0.9 & 452 \\
\hline
\end{tabular}

MPI1 = 1.5(2-MP+3-MP)/(P+1-MP+9-MP): $P$ - phenantrene, MP - methylphenantrene; MPR = 2-MP/1-MP, MPR1 $=(2-\mathrm{MP}+3-\mathrm{MP}) /(1-\mathrm{MP}+9-\mathrm{MP}+2-\mathrm{MP}+3-\mathrm{MP}) ; \mathrm{R}_{\mathrm{cal}}=0.60 \mathrm{MPI} 1+0.37$ for MPR<2.65 (Radke, 1988); $\mathrm{R}_{\mathrm{cal}(\mathrm{MPR})}=$ -0.166+2.242(MPR1) (Kvalheim et al., 1987); DBT - dibenzotiophene; MDR = 4-MDBT/1-MDBT: MDBT methyldibenzotiophene; $R_{\text {cal(DBT) }}=0.51+0.073 \mathrm{MDR} ; \mathrm{T}_{\max (\mathrm{DBT})}=423+5.1 \mathrm{MDR}$; for other explanations see Table 1

The methylphenanthrenes distribution indicate that both crude oil samples show almost equal maturity, indicating their generation in the peak of the oil window (Rcal ca. $0.8 \%$ ). The maturity indices calculated based on methyldibenzothiophenes distribution indicate small difference in oil maturity: 0.7 (Lp-4) and $0.9 \%(L p-8)$ on the vitrinite reflectance scale. As the MPI and MPR indices were worked out for terrestrial organic matter (e.g., Radke, 1988), the maturity described by the MDR values for the oils generated mostly from marine Type II kerogen is more precise. Sterane and terpane distributions generally con- firm the maturity of the oils analysed (Fig. 15) estimated from MDR values indicating the slight higher maturity of the Lp-8 oil. Dimethylpentane homologues distribution (Mango, 1997) indicates a temperature of generation of hydrocarbons in the range of 122 to $126^{\circ} \mathrm{C}$ (Table 4). Both maturity indices and estimates of temperature of generation of hydrocarbons for oils from the Lopushna field are within the range determined for oils accumulated in the Carpathian flysch sequence (Kotarba et al., 2007; Więcław et al., 2012). 


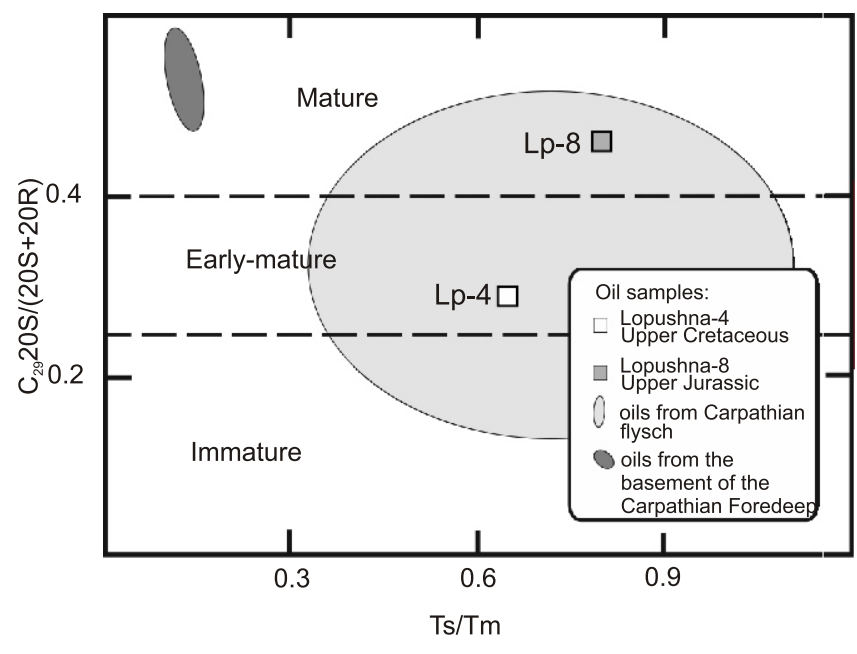

Fig. 15. Sterane $\mathrm{C}_{29} 20 \mathrm{~S} /(20 \mathrm{~S}+20 \mathrm{R})$ ratio versus $\mathrm{Ts} / \mathrm{Tm}$

Maturity fields after Peters and Moldovan (1993)

\section{OIL-SOURCE ROCK CORRELATION}

The earlier investigations (Koltun, 1992; Koltun et al., 1998 Kotarba et al., 2005, 2007; Kotarba and Koltun, 2006; Więcław et al., 2012) show that most of the oils accumulated within the Carpathian flysch strata belong to one oil family and that the organic-rich rocks of the Oligocene Menilite Beds of the Carpathian flysch sequence, having good source rock properties and occurring at the depth range covering the entire "oil window", are the source rocks for these oils.

For oil-source rock correlation we used the results of analyses of the Menilite Beds (Kotarba et al., 2005), occurring closest to the Lopushna field, which included 18 core samples from the Boryslav-Pokuttya Unit from Bytkiv-1001, Bytkiv-1003, Bytkiv-1004, Delyatyn-15, Pasichna-1, Pasichna-806 and Pivnichny Delyatyn-1 boreholes and 19 outcrop samples from the Skyba Unit from the Babche/Molodkiv and Pniv outcrops of the Outer Carpathians.

All the results of the Lopushna oils investigations reported above, indicating the genetic type and depositional environment of source rock organic matter, show evident correlation with the Menilite Beds. The latter contain low- and normal-sulphur Type II kerogen and have been deposited in marine clastic anoxic environments (Koltun, 1992; Koltun et al., 1998).

Correlation of the stable carbon isotope composition of crude oils and their individual fractions from the Lopushna field with data on oils accumulated in the Carpathian flysch strata indicates that they have been generated from the same genetic type of organic matter. Comparison of the isotopic "fingerprints" of the Lopushna oils with the isotope composition of bitumen and their individual fractions from the organic-rich rocks of the Menilite Beds (Fig. 14) indicate that the latter have evidently been the source for the oils. The Menilite Beds are a 300 to $1400 \mathrm{~m}$ thick succession, made up of intercalations of sandstones, siltstones and organic-rich argillites (e.g., Vialov et al., 1988). It is of Oligocene-Early Miocene age and occurs at the top of the Carpathian flysch sequence. Total organic carbon content in the argillites in most cases much exceeds $1 \%$, reaching locally over $20 \%$. The rocks contain Type II kerogen with excellent petroleum potential (Kotarba et al., 2013, 2014). In the frontal tectonic units the oil window occurs at a depth range from about 4 to 6 km (Koltun et al., 1998; Kosakowski, 2013).
The presence of oleanane in the Lopushna oils, which derives from the higher (angiosperm) plants and is evidence of the Cretaceous or younger age of the source kerogen (e.g., Ekweozor and Udo, 1988; Moldowan et al., 1994) means that the rocks of the Paleozoic to Jurassic sequence of the platform basement, underlying the Lopushna field, cannot be considered as possible source rocks for them. In turn, the oils accumulated in the Carpathian flysch sequence and bitumen from the organic-rich Oligocene Menilite Beds always contain oleanane (Kotarba et al., 2007; Więcław et al., 2012), which shows that the latter, which have been determined as source rocks for the Carpathian flysch oils (Koltun et al., 1998; Kotarba et al., 2005, 2007; Kotarba and Koltun, 2006), are evidently the source for the Lopushna oils too. Oleanane is absent in oils of the Kokhanivka and Orkhovychi fields of the basement of the Carpathian Foredeep (Kotarba et al., 2007; Więcław et al., 2012), which suggests their generation from Jurassic or older rocks of the platform sequence and distinctly shows that they belong to a different oil family than oils from the Carpathian flysch strata and the Lopuschna field.

The data reported above provide sufficient evidence to state that oil in the Lopushna field belongs to the petroleum system of the Outer Carpathians and to the same oil family as oils accumulated in the Cretaceous-Paleogene strata of the Boryslav-Pokuttya and Skyba units of the Ukrainian Carpathians.

\section{POSSIBLE MIGRATION PATHWAYS}

Fraction composition and saturate/aromatic hydrocarbon (sat/aro) ratios have been suggested to be influenced by migration distance. Contents of asphaltenes in the crude oils investigated of 2.0 and $0.9 \mathrm{wt} . \%$ (Table 1) are inversely correlated with low saturated-hydrocarbon content and low sat/aro ratios, which are respectively 2.4 and 5.3 (Table 1 ). The contents of asphaltenes of the Lopushna oils correlate with those of the oils accumulated in the Carpathian flysch strata, for which it varies from 0.2 to $4.3 \mathrm{wt} . \%$, while sat/aro ratios correspond to or exceed their range of 1.9 to 4.7 (Więcław et al., 2012). These data show that the migration distance for the Lopushna oils was similar or slightly longer, but in any case was comparable to that of the oils accumulated in the Carpathian flysch strata. This looks logical, taking into account that the Lopushna oil field occurs in the platform basement, covered by the Carpathian nappes, containing the Oligocene Menilite Beds and spatially rather close to them. The presence of oleanane in the Lopushna oils is further evidence of its migration from the Carpathian flysch strata. The very fact of its existence in the Jurassic oil envisages its migration from younger deposits. According to the results reported in this study, we accept that Lopushna oils have been sourced from the Menilite Beds, and therefore there must exist pathways of hydrocarbon migration from the younger Oligocene strata of the Carpathian Overthrust to the older Jurassic and Cretaceous reservoirs of the platform basement, occurring under the Carpathian Overthrust. There are a number of both longitudinal and transverse subvertical dislocations of rather great magnitude, formed under the load of the Carpathian nappes, on which the subsided flysch strata occur at the same depth level as the Jurassic and Cretaceous rocks of the platform basement. We can suggest several assumptions about the possible migration pathways. The NE-SW oriented Pokuttya transverse fault (Fig. 1) is the eastern boundary of the zone of maximum depth of flysch deposits occurrence (Ryłko and Tomaś, 2005). On its eastern limb the surface of consolidated basement rises abruptly and the depth of flysch 
臬 boreholes

$=$ thrusts

I fault

$\Rightarrow$ direction of oil migration

oil accumulation

Flysch

\begin{tabular}{|l|l|}
\hline $\mathrm{Pg}_{12}$ & Paleocene-Eocene \\
\hline
\end{tabular}

$\mathrm{Pg}_{3} \mathrm{ml}$ Oligocene Menilite Beds

$\mathrm{Cr}_{2}$ U.Cretaceous

Molasse

N,pl Miocene, Polyanytsya Beds

\begin{tabular}{|l|l}
\hline $\mathrm{N}, \mathrm{st}$ & Miocene Stebnyk Beds \\
\hline
\end{tabular}

$\mathrm{N}, \mathrm{bd}$ Miocene Badenian

Platform

$\mathrm{Cr}$ Cretaceous

Jurassic

D Devonian

$\mathrm{S}$ Silurian

$\mathrm{Cm}$ Cambrian

PR Proterozoic

Delyatyn-14 borehole projection about $3.2 \mathrm{~km}$ from NE

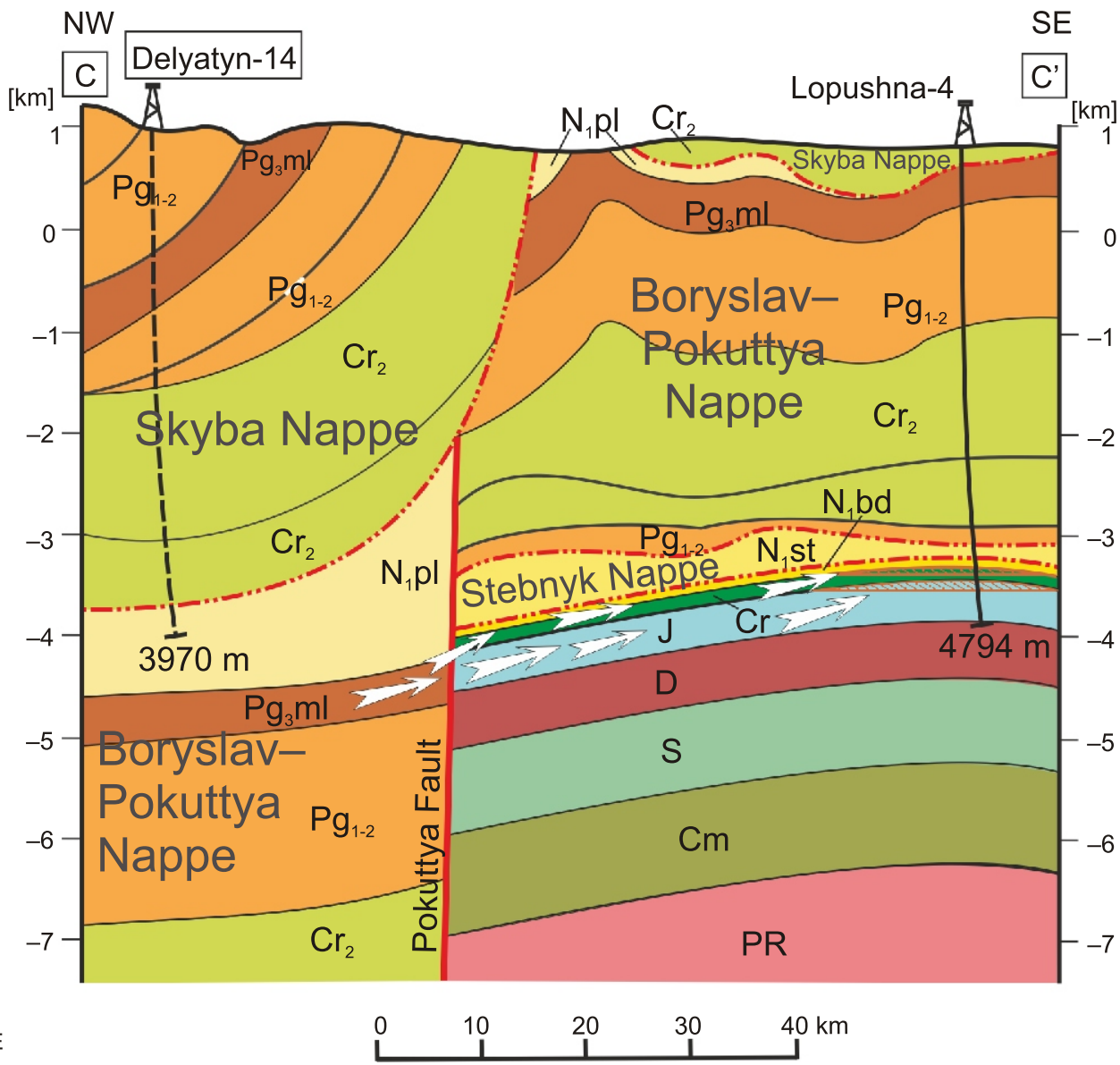

Fig. 16. Sketch geological cross-section along the frontal part of the Ukrainian Outer Carpathians in the vicinity of the Lopushna oil field and direction of petroleum migration pathways

Geology after Shakin et al. (1977), Fedyshyn (1998), Danysh et al. (2005) and Ryłko and Tomaś (2005)

deposits westwards from the fault greatly exceeds the depth of the platform Mesozoic strata eastwards from it. Figure 16 shows a sketch cross-section along the Carpathian nappes from the area of occurrence of several oil fields in the flysch strata, namely Bytkiv, Monastyrchany, Pasichna, Gvizd (see Fig. 1 for location), through the Pokuttya Fault to the Lopushna field.

Oils from these fields as well as the source rocks of the Menilite Beds from this region have been studied by us earlier (Kotarba et al., 2005). According to these data the Menilite organic-rich rocks reach the "oil window" in this area at depths of over $5 \mathrm{~km}$. Good correlation of these oils and source rocks with the Lopushna oils discussed in the previous chapters suggests the possibility of migration of hydrocarbons from the flysch strata through the Pokuttya dislocation to the Lopushna reservoirs. Another possibility might exist in the migration of hydrocarbons, generated from the Menilite Beds in the deep part of the Boryslav-Pokuttya Nappe, occurring under the Skyba Nappe (Fig. 2), the existence of which has been suggested by Gavura and Panov (1977) and Sheremeta et al. (2011) based on interpretation of geological, seismic and gravity data. One more migration pathway can be assumed from the Menilite Beds from the deep part of the Krosno Unit, occurring under the Chornogora and Porkulets nappes. However, this rather long-distance migration looks less likely than the previous op- tions, in particular as regards the asphaltenes and sat/aro ratio, similar to those of oils accumulated in the Carpathian flysch strata, which had a less distant migration pathway. The Lower Menilite Beds of the Krosno Unit of the study area have been investigated in the Grynyava-1 borehole (Koltun et al., 1998; see Figs. 1 and 2 for location). Within the depth interval of 4185-4366 m investigated the rocks with TOC content reaching 2.8 wt.\% occur in the lower part of the oil,and upper part of the "gas window". Hence, the migration of liquid hydrocarbons from the deeper part of the unit might only have taken place at an earlier stage of the Miocene overthrusting episode. Attention should be paid to the fact that natural oils reservoired in the Mesozoic basement in several fields of the Polish part of the Carpathian Foredeep appear to be predominantly derived and migrated from the Menilite Beds (ten Haven et al., 1993; Curtis et al., 2004). The Lopushna field is unique in containing this type of oil found in the Mesozoic-Paleogene strata of the platform basement under the Ukrainian Carpathian Overthrust.

\section{CONCLUSIONS}

The crude oils from two main accumulations of the Lopushna field investigated have similar geochemical characteristics. They did not undergo any extensive secondary processes and repre- 
sent low-sulphur oils, intermediate in API gravity, with maximum concentrations of $n$-alkane distributions usually at $n-\mathrm{C}_{9}-n-\mathrm{C}_{11}$ hydrocarbons. Distribution of $n$-alkanes, isoprenoids and biomarkers in these oils indicate the marine origin of source organic matter (Type II or mixed II/III kerogens) dispersed in clastic sediments deposited in suboxic environments. This type of kerogen has been identified for the Oligocene Menilite Beds of the Carpathian flysch strata (Koltun, 1992; Kotarba and Koltun 2006). The presence of oleanane in oils from the Lopushna field show that they have been sourced from rocks not older than Cretaceous, which excludes their correlation with the Paleozoic to Jurassic sequence of the platform basement. The maturity indices calculated based on the methyldibenzotiophenes distribution indicate an oil maturity from 0.7 to $0.9 \%$ on the vitrinite reflectance scale, and the dimethylpentane homologues distribution shows the temperature of generation of hydrocarbons to be in the range of 122 to $126^{\circ} \mathrm{C}$.

By all the geochemical characteristics obtained in this study, crude oils from the Lopushna field clearly correlate with the oils accumulated in the Carpathian flysch sequence, which allows us to consider them as part of the same oil family and hence it can be concluded that the Oligocene Menilite Beds of the Carpathian flysch sequence have clearly also sourced the Lopushna oils. This is supported by the good correlation of these oils in the distribution of $n$-alkanes, isoprenoids, biomarkers and stable carbon isotope composition of individual fractions with the bitumen from the organic-rich rocks of the Menilite Beds. Migration of hydrocarbons from the mature source rocks of the Menilite Beds to the reservoirs of the Lopushna field could have taken place through faults, along which the Carpathian flysch strata occur deeper than the Mesozoic rocks of the platform basement of the adjacent blocks. Such tectonic conditions could facilitate migration in both longitudinal and transverse directions against the Carpathian nappes.

The possibility of filling the reservoirs of the Mesozoic platform basement with the hydrocarbons generated within the Carpathian flysch strata suggests that other structures similar to the Lopushna field might have accumulated hydrocarbons and that new discoveries of fields of this kind are possible.

Acknowledgements. The geochemical study was undertaken as the statutory research of the Faculty of Geology, Geophysics and Environmental Protection at the AGH University of Science and Technology in Kraków, project No. 11.11.140.626. Analytical work by $\mathrm{T}$. Kowalski and $\mathrm{H}$. Zych from the AGH University of Science and Technology is gratefully acknowledged. We greatly appreciate comments and suggestions of improvements of the first version of this paper by $A$. Bechtel and M. Fabiańska.

\section{REFERENCES}

Claypool, G.E., Mancini, E.A., 1989. Geochemical relationships of petroleum in Mesozoic reservoirs to carbonate source rocks of Jurassic Smackover Formation, Southwestern Alabama. AAPG Bulletin, 73: 904-924.

Coplen, T.B., 2011. Guidelines and recommended terms for expression of stable-isotope-ratio and gas-ratio measurement results. Rapid Communications in Mass Spectrometry, 25: 2538-2560.

Curtis, J.B., Kotarba, M.J., Lewan, M.D., Więcław, D., 2004 Oil/source correlations in the Polish Flysch Carpathians and Mesozoic basement and organic facies of the Oligocene Menilite Shales: insights from hydrous pyrolysis experiments. Organic Geochemistry, 35: 1573-1596.

Danysh, V., Hnylko O., Pavlyuk, M., Tsarnenko, P., Jankowski, L., Kopciowski, R., Ryłko, W., Anastasiu N., Dragan E., Popa M., Roban R., 2005. Geological Map of the Outer Carpathians: Borderland of Ukraine and Romania, 1:200,000. Państwowy Instytut Geologiczny, Warszawa.

Didyk, B.M., Simoneit, B.R.T., Brassell, S.C., Eglinton, G., 1978 Organic geochemical indicators of palaeoenvironmental conditions of sedimentation. Nature, 272: 216-222.

Ekweozor, C.M., Udo, O.T., 1988. The oleananes: origin, maturation and limits of occurrence in Southern Nigeria sedimentary basins. Organic Geochemistry, 13: 131-140.

Fedyshyn, V.O., ed., 1998. Atlas of Oil and Gas Fields of Ukraine. Ukrainian Oil and Gas Academy, Lviv.

Fedyshyn, V.O., Havrylko, V.M., Kulchytski, D.Y., Karpenchuk, Y.R., Tkachenko, A.I., 2001. Results of prospecting-exploration works and industrial exploration of gas reserves in the Bilche-Volytsia zone of the Precarpathian foredeep and prospects of the new gas fields prospecting (in Ukrainian with English summary). Geologiya i geokhimiya goryuchykh kopalyn, (4): 3-23.

Galimov, E.M., 1973. Carbon Isotopes in Petroleum Geology (in Russian). Izd. Nedra, Moskva.

Galimov, E.M., 1986. Isotopic method of explanation of source rocks for examples of petroleum fields of selected Soviet Union regions (in Russian). Izvestiya Akademii Nauk SSSR, Seriya Geologicheskaya, 4: 3-21.
Gavrylyshyn, V.I., 1998. Stratigraphy of the platform deposits of Mesozoic of the subthrust of the Ukrainian Carpathians (in Ukrainian). Geologiya i geokhimiya goryuchykh kopalyn, (3): $81-90$

Gavura, S.P., Panov, G.M., 1977. About the deep structure and oiland gas-prospects of the Pokuttya-Bukovyna Carpathians (in Russian). Geologiya i geokhimiya goryuchykh kopalyn, 49: 15-23.

Halpern, H.I., 1995. Development and applications of light-hydrocarbon-based star diagrams. AAPG Bulletin, 79: 801-815.

Hughes, W.B., Holba, A.G., Dzou, L.I.P., 1995. The ratios of dibezotiophene to phenantrene and pristane to phytane as indicators of depositional environment and lithology of petroleum source rocks. Geochimica et Cosmochimica Acta, 59: 3581-3598.

Khavenzon, I., Pylypyshyn, B., Hnevush, O., Huk, I., Denys, M., 2011. Forecast of oil-and-gas-bearing of Lopushna oil and gas field using the technique of seismolitmological analysis (in Ukrainian with English summary). Geodynamika, 2: 317-319.

Koltun, Y.V., 1992. Organic matter in Oligocene Menilite Formation rocks of the Ukrainian Carpathians: palaeoenvironment and geochemical evolution. Organic Geochemistry, 18: 423-430.

Koltun, Y.V., Espitalié, J., Kotarba, M., Roure, F., Ellouz, N., Kosakowski, P., 1998. Petroleum generation in the Ukrainian external Carpathians and the adjacent foreland. Journal of Petroleum Geology, 21: 265-288.

Kosakowski, P., 2013. 1D modelling of hydrocarbon generation and expulsion from Oligocene Menilite source rocks in the San and Stryi rivers region (Polish and Ukrainian Carpathians). Geological Quarterly, 57 (2): 307-324.

Kosakowski, P., Leśniak, G., Krawiec, J., 2012. Reservoir properties of the Palaeozoic-Mesozoic sedimentary cover in the Kraków-Lubaczów area (SE Poland). Annales Societatis Geologorum Poloniae, 82: 51-64.

Kotarba, M.J., Koltun, Y.V., 2006. The origin and habitat of hydrocarbons of the Polish and Ukrainian Parts of the Carpathian Province. AAPG Memoir, 84: 395-442. 
Kotarba, M.J., Więcław, D., Koltun, Y.V., Lewan, M.D., Marynowski, L., Dudok, I.V., 2005. Organic geochemical study and genetic correlations between source rocks and hydrocarbons from surface seeps and deep accumulations in the Starunia area, fore-Carpathian region, Ukraine. In: Polish and Ukrainian geological studies (2004-2005) at Starunia - the area of discoveries of woolly rhinoceroses (ed. M.J. Kotarba): 125-145. Polish Geological Institute and Society of Research on Environmental Changes "Geosphere", Warszawa-Kraków.

Kotarba, M.J., Więcław, D., Koltun, Y.V., Marynowski, L., Kuśmierek, J., Dudok, I.V., 2007. Organic geochemical study and genetic correlation of natural gas, oil and Menilite source rocks in the area between San and Stryi rivers (Polish and Ukrainian Carpathians). Organic Geochemistry, 38 : 1431-1456

Kotarba, M.J., Peryt, T.M., Koltun, Y.V., 2011a. Microbial gas system and prospectives of hydrocarbon exploration in Miocene strata of the Polish and Ukrainian Carpathian Foredeep. Annales Societatis Geologorum Poloniae, 81: 523-548.

Kotarba, M.J., Więcław, D., Kosakowski, P., Wróbel, M., Matyszkiewicz, J., Buła, Z., Krajewski, M., Koltun, Y.V., Tarkowski, J., 2011b. Petroleum systems in the Paleozoic-Mesozoic basement of the Polish and Ukrainian Carpathian Foredeep. Annales Societatis Geologorum Poloniae, 81: 487-522.

Kotarba, M.J., Więcław, D., Dziadzio, P., Kowalski, A., Bilkiewicz, E., Kosakowski, P., 2013. Organic geochemical study of source rocks and natural gas and their genetic correlation in the central part of the Polish Outer Carpathians. Marine and Petroleum Geology, 45: 106-120.

Kotarba, M.J., Więcław, D., Dziadzio, P., Kowalski, A., Kosakowski, P., Bilkiewicz, E., 2014. Organic geochemical study of source rocks and natural gas and their genetic correlation in the eastern part of the Polish Outer Carpathians and Palaeozoic-Mesozoic basement. Marine and Petroleum Geology, 56: 97-122.

Kruglov, S.S., Smirnov, S.E., Spitkovskaya, S.M., Filshtynski, L.E., Hizhniakov, A.V., 1985. Geodynamics of the Carpathians (in Russian). Naukova Dumka, Kiev.

Krzywiec, P., Florek, R., Popadyuk, I., 2009. Polish-Ukrainian Carpathian subthrust prospects - selected problems. AAPG European Reg. Ann. Conf., Paris-Malmaison, France, November 23-24, Book of Abstracts, 71-74. Available from: http://www.searchanddiscovery.com/pdfz/abstracts/pdf/2009/europe/abstracts/ndx_krzywiec.pdf.html

Kvalheim, O. M., Christy, A. A., Telnæs, N., Bjŭrseth, A., 1987. Maturity determination of organic matter in coals using the methylphenantrene distribution. Geochimica et Cosmochimica Acta, 51: 1883-1888.

Lafargue, E., Ellouz, N., Roure, F., 1994. Thrust-controlled exploration plays in the outer Carpathians and their foreland (Poland, Ukraine and Romania). First Break, 12: 69-79.

Lewan, M.D., 1984. Factors controlling the proportionality of vanadium to nickel in crude oils. Geochimica et Cosmochimica Acta, 48: 2231-2238.

Mango, F.D., 1997. The light hydrocarbons in petroleum: a critical review. Organic Geochemistry, 26: 417-440.

Moldowan, J.M., Seifert, W.K., Gallegos, E.J., 1985. Relationship between petroleum composition and depositional environment of petroleum source rocks. AAPG Bulletin, 69: 1255-1268.

Moldowan, J.M., Dahl, L., Huizinga, B.J., Fago, F.J., Hickey, L.J., Peakman, T.M., Taylor, D.W., 1994. The molecular fossil record of oleanane and its relation to angiosperms. Science, 265 : 768-771.

Ogorodnik, M.E., 2005. Geochemical and palynological aspects of investigation of Lower Cretaceous deposits of the autochthon of the Pokuttyan-Bukovynian Carpathians (in Ukrainian with English summary). Geologiya i geokhimiya goryuchykh kopalyn, (1): $59-67$.

Orr, W.L., 1986. Kerogen/asphaltene/sulfur relationships in sulfur-rich Monterey oils. Organic Geochemistry, 10: 499-516.

Orr, W.L., 2001. Evaluating kerogen sulfur content from crude oil properties: cooperative Monterey organic geochemistry study. In: The Monterey Formation. From Rocks to Molecules (eds.
C.M. Isaacs and J. Rullkötter): 348-367. Columbia University Press, New York.

Oszczypko, N., Krzywiec, P., Popadyuk, I., Peryt, T., 2006. Carpathian Foredeep Basin (Poland and Ukraine) - its sedimentary, structural and geodynamic evolution. AAPG Memoir, 84: 293-350.

Peters, K.E., Walters, C.C., Moldowan, J.M., 2005. The biomarker guide. Biomarkers and isotopes in petroleum exploration and earth history. Ed. 2. University Press, Cambridge.

Picha, F.J., 1996. Exploring for hydrocarbons under thrust belts - a challenging new frontier in the Carpathians and elsewhere. AAPG Bulletin, 80: 1547-1564.

Radke, M., 1988. Application of aromatic compounds as maturity indicators in source rocks and crude oils. Marine and Petroleum Geology, 5: 224-236.

Radkovets, N.Y., 1999. Petrographic characteristics of Upper Albian-Lower Cenomanian deposits of the autochthon of the Pokuttian-Bukovynian part of the Ukrainian Carpathians (in Ukrainian with English summary). Geologiya i geokhimiya goryuchykh kopalyn, (3): 116-122.

Radkovets, N.Y., 2010. On genesis of organic-rich palaeo-shelf Cretaceous deposits of the East-Carpathian segment of Tethys ocean (in Ukrainian with English summary). Zbirnyk naukovykh prats Instytutu geologichnykh nauk NAN Ukrainy, 3: 69-75.

Radkovets, N.Y., 2015. Early Cretaceous anoxic sedimentogenesis in the Carpathian segment of Meso-Tethys (in Ukrainian with English summary). Geologiya i geokhimiya goryuchykh kopalyn, (3-4) (in press).

Radkovets, N., Yaremchuk, Y., 2006. Structural features of authigenic glauconite of Albian-Cenomanian sandstones of the autochthon of the Pokuttian-Bukovynian part of the Ukrainian Carpathians in context of oil- and gas-bearing (in Ukrainian with English summary). Geologiya i geokhimiya goryuchykh kopalyn, (1): 59-64

Roure, F., Sassi, W., 1995. Kinematics of deformation and petroleum system appraisal in Neogene foreland fold-and-thrust belts. Petroleum Geosciences, 1: 253-269.

Ryłko, W.T., Tomaś, A., 2005. Basement structure below the West-Carpathian-East-Carpathian orogen junction (eastern Poland, north-eastern Slovakia and western Ukraine). Geologica Carpathica, 56: 29-40.

Shakin, V., Burov, V., Vialov, O., Glushko, V., Kruglov, S., Petrashkevich, M., Temnjuk, M., 1976. Geological map of the Ukrainian Carpathians and adjoining areas 1:200,000. KyivGeologia, Kyiv.

Sheremeta, P.M., Slonytska, S.G., Trehubenko, V.I., Ladyzhenskyy, Y. M., Nazarevych, A.V., Nazarevych, L.Y., Havenzon, I.V., Levkovych, Y.M., 2011. About deep structure of lithosphere of western region of Ukraine by data of complex of geophysical researches (in Ukrainian with English summary). Geodynamika, 2: 341-343.

ten Haven, H.L., Lafargue, E., Kotarba, M., 1993. Oil/oil and oil/source rock correlations in the Carpathian Foredeep and the Carpathian Overthrust, South-East Poland. Organic Geochemistry, 20: 935-959.

Thompson, K.F.M., 1987. Fractionated aromatic petroleums and the generation of gas-condensates. Organic Geochemistry, 11: 573-590.

Vialov, O.S., Gavura, S.P., Danysh, V.V., Lemishko, O.D., Leshchukh, P.I., Ponomaryova, L.D., Romaniv, A.M., Smirnov, S.E., Smolinskaya, N.I., Tsarnenko, P.N., 1988. Stratotypes of the Cretaceous and Paleogene deposits of the Ukrainian Carpathians (in Russian). Naukova Dumka, Kiev.

Więcław, D., 2011. Origin of liquid hydrocarbons accumulated in the Miocene strata of the Polish Carpathian Foredeep and its Paleozoic-Mesozoic basement. Annales Societatis Geologorum Poloniae, 8: 443-458.

Więcław, D, Kotarba, M. J, Kowalski, A., 2010. Origin of oils accumulated in the Middle Cambrian reservoirs of the Polish part of the Baltic region. Geological Quarterly, 54 (2): 205-216.

Więcław, D., Kotarba, M.J., Kowalski, A., Koltun, Y.V., 2012. Origin and maturity of oils in the Ukrainian Carpathians and their Mesozoic basement. Geological Quarterly, 56 (1): 158-168. 